\title{
KNJIŽNIČNI IZVORI I USLUGE ZA MOBILNE UREĐAJE U VISOKOŠKOLSKIM I SRODNIM KNJIŽNICAMA
}

\author{
LIBRARY RESOURCES AND SERVICES FOR MOBILE \\ DEVICES IN ACADEMIC AND RELATED LIBRARIES
}

\author{
Ivana Pažur ${ }^{l}$ \\ Centar za znanstvene informacije \\ Instituta Ruđer Bošković \\ ipazur@irb.hr
}

UDK / UDC [027.625+004.78]:027.7

Znanstvena bilješka / Preliminary communication

Primljeno / Received: 17. 7. 2019.

Prihvaćeno / Accepted: 21. 10. 2019.

\section{Sažetak}

Cilj. Rad utvrđuje zastupljenost knjižničnih izvora i usluga prilagođenih za pristup putem mobilnih uređaja kod visokoškolskih i srodnih knjižnica koje podupiru znanstveni rad i visoko obrazovanje: Nacionalna i sveučilišna knjižnica u Zagrebu, sveučilišne knjižnice, općeznanstvene i specijalne knjižnice - instituti i zavodi.

Pristup/metodologija/dizajn. Postavljena su tri istraživačka pitanja: 1) Koliko su se razmatrane visokoškolske i srodne knjižnice prilagodile korisnicima u smislu dostupnosti knjižničnih izvora i usluga za mobilne uređaje? 2) Koje su vrste knjižničnih izvora i usluga za mobilne uređaje u većoj, a koje u manjoj mjeri zastupljene u razmatranim visokoškolskim i srodnim knjižnicama? 3) Kakve su sličnosti i razlike između pojedinih kategorija razmatranih knjižnica s obzirom na implementiranost analiziranih knjižničnih izvora i usluga za mobilne uređaje? U provedbi istraživanja napravljena je analiza sadržaja 97 knjižničnih mrežnih mjesta prema 10 zadanih kriterija, a prisutnost svakog pojedinog kriterija s manje ili jednako 50 \% smatrana je nedovoljnom zastupljenošću.

1 Ovaj se rad temelji i proširuje rezultate dijela istraživanja predstavljenih u poglavlju Sadržajna analiza mrežnih stranica visokoškolskih knjižnica Sveučilišta u Zagrebu u okviru doktorskog rada Komunikacijski model korištenja mobilnih knjižničnih usluga u visokoškolskim knjižnicama Ivane Pažur, napisanog pod mentorstvom Ivane Hebrang Grgić i Ljubice Bakić-Tomić i obranjenog 17. 6. 2019. godine na Filozofskom fakultetu u Zagrebu. 
Rezultati. Responzivne mrežne stranice zastupljene su kod 43 \% knjižnica. Najzastupljenije su kod sveučilišnih i općeznanstvenih knjižnica (obje kategorije s po 50 \%), slijede institutske i zavodske knjižnice ( $45 \%$ ), a najmanje su zastupljene među visokoškolskim knjižnicama (42\%). Samo jedna knjižnica (1 \%) ima knjižničnu aplikaciju za mobilne uređaje. Nijedna razmatrana knjižnica nema aplikaciju knjižničnog kataloga za mobilne uređaje, dok $13 \%$ knjižničnih kataloga ima responzivno mrežno sučelje. Knjižnice ne upućuju korisnike na pristup putem mobilnih uređaja bazama znanstvenih informacija i podataka, e-knjigama ili e-časopisima. Komunikaciju s korisnicima pomoću tekstualnih poruka ne nudi nijedna knjižnica. Profil na društvenoj mreži Facebook posjeduje $23 \%$ knjižnica. Primjena novih tehnologija i usluga (QR, NFC, Beacon, AR) ne spominje se na većini mrežnih stranica razmatranih knjižnica i zastupljena je u rijetkim pojedinačnim slučajevima. Ukupno 29 \% razmatranih knjižnica omogućava objedinjeno pretraživanje svih dostupnih e-izvora (discovery search): nude ga sve sveučilišne knjižnice (100 \%), od visokoškolskih knjižnica nudi ga $28 \%$, a od institutskih i zavodskih knjižnica $20 \%$. Edukaciju o knjižničnim izvorima i uslugama za mobilne uređaje eksplicitno na svojim mrežnim stranicama ne spominje nijedna knjižnica. Od ukupnog broja razmatranih knjižnica čak 44 \% knjižnica nema zadovoljen nijedan kriterij analize sadržaja, a od 10 kriterija najviše (30 \%) ih je zastupljeno kod osam knjižnica. Rezultati pokazuju da izvori i usluge za mobilne uređaje nisu dovoljno (manje ili jednako $50 \%$ ) zastupljeni u ukupnom broju razmatranih knjižnica, kao ni kod pojedinačnih knjižnica.

Originalnost/vrijednost. Prvi put je razmotrena i napravljena analiza sadržaja knjižničnih izvora i usluga hrvatskih knjižnica za mobilne uređaje, što daje uvid u postojeću situaciju i poticaj za razmišljanje o orijentaciji prema korisnicima takvih usluga.

Ključne riječi: knjižnični izvori, visokoškolske knjižnice, usluge za mobilne uređaje.

\section{Abstract}

Purpose. This paper establishes the availability of library resources and services adapted for access from mobile devices in academic and related libraries that support scientific work and higher education: The National and University Library in Zagreb and other university libraries, general scientific, and special libraries - institutes.

Approach/methodology/design. Three research questions were asked: 1) To what extent have the academic and related libraries adapted to users in terms of the availability of library resources and services on mobile devices? 2) What types of mobile library resources and services are represented to a greater extent and which ones are less represented in the researched academic and related libraries? 3) What are the similarities and differences between the different categories of the researched libraries with regard to the implementation of the analyzed library resources and services for mobile devices? The research was conducted on the sample of 97 library websites according to 10 content criteria, and each criteria with the presence less than or equal to $50 \%$ was considered underrepresented. 
Findings. The responsive web design is present on $43 \%$ library websites. It is most prevalent in university and general scientific libraries (both categories with $50 \%$ each), followed by institutes libraries (45\%), and the least represented among academic libraries $(42 \%)$. Only one library $(1 \%)$ has a library mobile application. None of the researched libraries has a mobile catalog application, while $13 \%$ of library catalogs have a responsive Web interface. Libraries do not direct users to access online databases, e-books or e-journals from mobile devices. Communication with users via text messaging is not provided by any library. $23 \%$ of the libraries have Facebook profiles. The application of new technologies and services (QR, NFC, Beacon, AR) is not mentioned on most of the libraries' websites and is represented in rare individual cases. A total of $29 \%$ of the researched libraries enable a discovery search of all e-sources: it is offered by all university libraries (100\%), 28\% of academic libraries, and 20\% of special libraries. Education on the use of library mobile resources and services is not explicitly mentioned on any of the researched library websites. Out of the total number of the researched libraries, as many as $44 \%$ of libraries do not meet any of the content analysis criteria, and out of the 10 content criteria, the largest percentage of them $(30 \%)$ is present in 8 libraries. The research findings have shown that the resources and services for mobile devices are not sufficiently represented (less than or equal to $50 \%$ ) in the total number of the researched libraries nor in the individual libraries.

Originality/value. For the first time, an analysis of the Croatian mobile library resources and services has been made and discussed, which provided an insight into the current situation and can give an incentive to consider the user needs for such services in the future.

Keywords: academic libraries, mobile library resources, mobile services, m-services.

\section{Uvod}

Snažan tehnološki razvoj u kratkom je vremenu doveo do nastanka i daljnjeg ubrzanog razvoja raznovrsnih vrsta mobilnih uređaja koji se neprekidno razvijaju nudeći sve veći broj funkcija, pa među njima često više nema velikih razlika. Među mobilnim uređajima dominira pametni telefon (engl. smartphone), a nakon njega po popularnosti dolazi pločasto računalo ili tablet ${ }^{2,3,4}$; još se koriste e-čitači (engl. e-readers), malena prijenosna računala (engl. netbook), uređaji koji su hi-

\footnotetext{
2 Digital in 2018: global overview. 2018. [citirano: 2018-12-16]. Dostupno na: https://www.slideshare.net/wearesocial/digital-in-2018-global-overview-86860338?qid=7833f8c4-07ae-49759d18-61aef3fdb3e6\&v=\&b=\&from_search $=1$.

3 Dahlstrom, E.; C. Brooks; S. Grajek; J. Reeves. ECAR study of undergraduate students and information technology, 2015. [citirano: 2019-7-10]. https://library.educause.edu/resources/2015/8/ /media/24ddc1aa35a5490389baf28b6ddb3693.ashx.

4 Pažur, I. Komunikacijski model korištenja mobilnih knjižničnih usluga u visokoškolskim knjižnicama: doktorski rad. Zagreb: Filozofski fakultet, 2019. Str. 109.
} 
bridi između pametnog telefona i tableta (engl. phablet), hibridi između prijenosnog računala i tableta (engl. laplet), uređaji za igre i dlanovni medijski uređaji (iPods). ${ }^{5}$ Zajednička im je mogućnost korištenja mobilnog interneta, lakoća i praktična veličina koje omogućavaju prenošenje i korištenje u pokretu što je potaknulo njihovo brzo širenje i prihvaćanje.

Korištenje mobilnih uređaja globalna je pojava zbog čega se govori o „eri mobilnih uređaja", a s obzirom na to da sve više potiskuju osobna računala, govori se i o ,post PC-eri”. ${ }^{6}$ Većina osoba posjeduje čak nekoliko vrsta različitih mobilnih uređaja koje koriste ovisno o mjestu, situaciji ili potrebnim sadržajima. Mlađe generacije, naročito studenti, najčešće posjeduju prijenosno računalo, a uz njega od mobilnih uređaja pametni telefon i tablet, međutim 2015. je u SAD-u zabilježeno da je broj studenata koji posjeduju pametni telefon po prvi put premašio broj studenata koji posjeduju prijenosno računalo. ${ }^{7}$

Dostupnost interneta putem mobilnih uređaja koji su stalno nadohvat ruke utječe na ponašanje korisnika, odnosno na način na koji koriste, pretražuju i prikupljaju informacije. ${ }^{8}$ Mlađe generacije očekuju stalni dotok informacija na bilo kojem mjestu i u bilo koje vrijeme pa se govori o tzv. generaciji koja trenutno očekuje informacije (engl. information now generation). ${ }^{9}$ Pametni je telefon mnogim pripadnicima mlađe populacije postao osnovni uređaj za pristup informacijama. Milenijci ili Y-generacija (osobe rođene između 1980. i 1994.) prvi su odrasli uz nove informacijsko-komunikacijske tehnologije (DVD, SMS, internet), a internet im je postao glavni informacijski izvor i kanal za komunikaciju u stvarnom vremenu. Pripadnici Google-generacije (tzv. Z-generacije ili novih milenijaca rođenih nakon 1995. godine) ne poznaju svijet bez mobitela, računala i interneta i brzo prihvaćaju nove uređaje, a navigacija putem dodira na zaslonu za njih je uobičajena mogućnost (tzv. engl. touch screen mentalitet). Za razliku od prijašnjih generacija isključivo se koriste pretraživačima, najčešće Googleom, i vole interaktivne sadržaje. ${ }^{10}$

\footnotetext{
5 Liu, Y. Q.; S. Briggs. A library in the palm of your hand: mobile services in top 100 University libraries. // Information Technology \& Libraries 34, 2(2015), 133-48. [citirano: 2019-10-17]. Dostupno na: https://ejournals.bc.edu/index.php/ital/article/view/5650.

6 Rawlins, B. Mobile devices: a practical guide for librarians. Lanham: Rowman \& Littlefield Publishers, 2015. Str. 5.

7 Dahlstrom, E.; C. Brooks; S. Grajek; J. Reeves. Nav. dj., str. 13.

8 Nowlan, G. Going Mobile: creating a mobile presence for your library // New Library World 114, 3/4(2013), 142-50. [citirano: 2019-10-17]. Dostupno na: https://doi. org/10.1108/03074801311304050.

9 Jacobs, M. L. Libraries and the mobile revolution: remediation=relevance. // Reference Services Review 37, 3(2009), 286-90. [citirano: 2019-3-11]. Dostupno na: https://doi. org/10.1108/00907320910982776.

10 Dahlstrom, E.; C. Brooks; S. Grajek; J. Reeves. Nav. dj.; Stropnik, A. Knjižnica za nove generacije: virtualni sadržaji i usluge za mlade. Zagreb: Hrvatsko knjižničarsko društvo, 2013. Str. 13-15. i 39-45.
} 
Broj korisnika pametnih telefona u svijetu je u 2019. godini premašio tri milijarde ${ }^{11}$, a predviđa se da će se još povećati za nekoliko stotina milijuna u narednih nekoliko godina, dok je broj korisnika mobilnih uređaja već 2018. prešao pet milijardi. ${ }^{12}$ Do ubrzanog širenja pametnog telefona dolazi nakon pojave iPhonea 2007. godine kod kojega su se sve naredbe po prvi put počele davati dodirom po zaslonu i s kojim se pojavljuju aplikacije za mobilne uređaje (engl. mobile apps). Tada dolazi i do promjene u demografiji korisnika, odnosno prevladavaju mlađi korisnici ispod trideset godina, poglavito studenti. ${ }^{13}$ Primjerice u 2014. godini $86 \%$ studenata u SAD-u je posjedovalo pametni telefon ${ }^{14}$, a 2015 . čak $92 \% .^{15}$ Istraživanje provedeno u Hrvatskoj 2015. godine pokazalo je da više od polovine korisnika usluga za mobilne uređaje (engl. mobile services) posjeduje pametni telefon (55\%), što je za gotovo 20 postotnih bodova više nego samo godinu dana ranije. ${ }^{16}$ Prognoza rasta broja korisnika pametnih telefona u Hrvatskoj od 2015. do 2022. godine predviđa da će broj mjesečno aktivnih korisnika 2022. dosegnuti 2,69 milijuna pojedinaca. ${ }^{17}$ Pametnom telefonu i u Hrvatskoj su najskloniji mlađi, obrazovaniji korisnici, poglavito studenti i učenici, kao i osobe s višim prihodima. Glavna funkcionalnost pametnog telefona jest pristup internetu što pokazuju i podaci prema kojima internet u Hrvatskoj koristi čak $92 \%$ vlasnika pametnih telefona. Vrijeme korištenja produljuje se pa tako gotovo $70 \%$ korisnika pretražuje mrežne stranice na pametnom telefonu više od 30 minuta dnevno, a među mlađima od 24 godine čak $91 \%$. Korištenje u pokretu korisnicima je posebno važno, pa tako četiri petine ispitanika koriste internet i izvan kuće, pritom koristeći isključivo pristup mobilnim mrežama treće i četvrte generacije (tzv. 3G/4G) ili kombinirajući mobilni pristup i fiksne pristupne točke. ${ }^{18}$ Prema podacima za 2017. godinu, $68 \%$ građana Hrvatske koristilo je pametni telefon (65\% u 2016.), $94 \%$ ih je koristilo i mobilni i pametni telefon, $27 \%$ je koristilo tablet, a ukupno $68 \%$

11 Holst, A. Number of smartphone users worldwide 2016-2021, 2019. // Statista. [citirano: 2019-9-10]. Dostupno na: https://www.statista.com/statistics/330695/number-of-smartphone-users-worldwide/.

12 Digital in 2018. Nav. dj., str. 7.

13 Rawlins, B. Nav. dj., str. 6.

14 Dahlstrom, E.; J. Bichsel. ECAR study of undergraduate students and information technology, 2014. [citirano: 2018-12-11]. Dostupno na: https://library.educause.edu/ /media/files/library/2014/10/ers1406-pdf.pdf?la=en.

15 Dahlstrom, E.; C. Brooks; S. Grajek; J. Reeves. Nav. dj., str. 13.

16 Hrvatski Telekom predstavio nove mobilne tarife i istraživanje o navikama korištenja smartfona u Hrvatskoj, 2015. [citirano: 2019-9-10]. Dostupno na: https://www.t.ht.hr/press-centar/ objave-za-medije/2195/Hrvatski-Telekom-predstavio-nove-mobilne-tarife-i-istrazivanje-o-navikama-koristenja-smartfona-u-Hrvatskoj.html.

17 O’Dea, S. Croatia: number of smartphone users 2015-2022. // Statista. [citirano: 2019-9-11]. Dostupno na: https:/www.statista.com/statistics/566069/predicted-number-of-smartphone-users-in-croatia/.

18 Hrvatski Telekom predstavio nove mobilne tarife i istraživanje o navikama korištenja smartfona u Hrvatskoj. Nav. dj. 
koristilo je stolno računalo, prijenosno računalo i malo prijenosno računalo (engl. netbook). Premda je korištenje osobnog i prijenosnog računala i dalje visoko zastupljeno, $45 \%$ ispitanika za pristup internetu jednako je koristilo pametni telefon, računalo i tablet, a čak $29 \%$ za pristup je prednost dalo pametnom telefonu. ${ }^{19}$ Broj jedinstvenih korisnika mobilnih uređaja 2018. u Hrvatskoj čini $80 \%$ od ukupnog broja stanovnika, dok broj korisnika mobilnog interneta čini $64 \%{ }^{20}$ Premda se u Hrvatskoj internetu poglavito pristupa pomoću prijenosnog i osobnog računala, očit je porast pristupa pomoću pametnog telefona i mobilnih uređaja općenito, po čemu se slijedi svjetski trend rasta mobilnog pristupa. To potkrepljuju globalni statistički podaci prema kojima je korištenje interneta putem mobilnih uređaja ${ }^{21}$ u listopadu 2016. dosegnulo 51,3 \%. ${ }^{22}$ Godinu ranije Google je izvijestio kako je broj pretraživanja s mobilnih uređaja premašio broj upita s osobnih računala. ${ }^{23}$

Podaci o posjedovanju i općem porastu pristupa internetu uz pomoć pametnog telefona i mobilnih uređaja općenito, u svijetu i u Hrvatskoj, govore u prilog njihove sve veće raširenosti. U relativno kratkom razdoblju napravljen je velik tehnološki napredak u razvoju mobilnih uređaja, a s uvođenjem umjetne inteligencije i proširene stvarnosti već se nazire novi smjer u kojem bi daljnji razvoj mogao ići i koji bi mogao donijeti promjene u njihovu izgledu, funkcioniranju i mogućnostima.

\section{Knjižnični izvori i usluge za mobilne uređaje}

Knjižničari su razmatrali isplativost uvođenja knjižničnih izvora i usluga za mobilne uređaje (engl. mobile services ili m-services) s obzirom na potrebna financijska sredstva, vrijeme i osoblje te s obzirom na to da mobilni korisnici prednost daju zabavnim aktivnostima i sadržajima. ${ }^{24}$ Međutim s vremenom su mnoga istraživanja zabilježila zainteresiranost korisnika i za edukacijske/akademske sadržaje te su knjižničari dobili nove spoznaje o zahtjevima i ponašanju korisnika

19 Consumer barometer from Google. [citirano: 2018-11-11]. Dostupno na: https://www.consumerbarometer.com/en/.

20 Digital in 2018 in Southern Europe part 2 - East. 2018. [citirano: 2018-11-16]. Dostupno na: https://www.slideshare.net/wearesocial/digital-in-2018-in-southern-europe-part-2-east-86864768.

21 Odnosi se na pristup putem pametnog telefona (46,53\%) i tableta $(4,73 \%)$.

22 Mobile and tablet internet usage exceeds desktop for first time worldwide. // StatCounter global stats. [citirano: 2019-9-10]. Dostupno na: http://gs.statcounter.com/press/mobile-and-tablet-internet-usage-exceeds-desktop-for-first-time-worldwide.

23 Sterling, G. It's official: Google says more searches now on mobile than on desktop. // Search Engine Land, 2015. [citirano: 2018-9-12]. Dostupno na: http://searchengineland.com/its-official-google-says-more-searches-now-on-mobile-than-on-desktop-220369.

24 Tomić, D. Raste broj korisnika pametnih mobilnih telefona. // ICT Business, 2015. [citirano: 2018-8-19]. Dostupno na: http://www.ictbusiness.info/internet/ht-raste-broj-korisnika-pametnih-mobilnih-telefona; također, Purcell, K.; R. Entner; N. Henderson. The rise of apps culture, Pew Research Center, 2010. [citirano: 2019-5-7]. Dostupno na: http://www.pewinternet. org/2010/09/14/the-rise-of-apps-culture/. 
mobilnih uređaja što je utjecalo i na veću angažiranost oko zadovoljavanja njihovih potreba. ${ }^{25} \mathrm{U}$ svega nekoliko godina, od 2010. do 2015., došlo je do jačeg širenja knjižničnih izvora i usluga za mobilne uređaje, no unatoč predviđanjima kako će oni do 2015. postati uobičajeni u gotovo svim knjižnicama, to se nije ostvarilo. ${ }^{26} \mathrm{U}$ ranijim istraživanjima korisnici knjižnične izvore i usluge za mobilne uređaje nisu smatrali važnima, no iako prema kasnijim istraživanjima interes raste i većina studentske populacije smatra kako će mobilna tehnologija unaprijediti knjižnične usluge i naročito pristup knjižnici, prisutan je i dio korisnika koji nisu sigurni jesu li takve usluge potrebne i bi li ih koristili. ${ }^{27} \mathrm{~S}$ obzirom na sadržaje koje knjižnice nude na mrežnim stranicama prilagođenima za mobilne uređaje, korisnici su u ranijim istraživanjima najbitnijima smatrali priručne, odnosno pasivne informacije, kao što su radno vrijeme, lokacija i kontakt. Također, prednost općenito daju izvorima i uslugama koje omogućavaju brzi pristup informacijama pa su im tako mogućnost produljenja posudbe i provjera knjižničnog korisničkog računa među najzanimljivijim uslugama. ${ }^{28}$ No iako su priručne informacije prema kasnijim istraživanjima i dalje visoko rangirane, vidljivo je da su korisnici postali zainteresirani i za pristup složenijim knjižničnim izvorima i uslugama kao što su baze znanstvenih informacija i podataka, knjižnični katalog, elektroničke knjige, rezervacije nastavnih sadržaja, studijskih soba i opreme i sl. Korisnici pokazuju želju i za preuzimanjem članaka i citata, žele čak i mogućnost lociranja i provjere dostupnosti primjeraka građe na polici, a zainteresirani su i za korištenje knjižničnih aplikacija za mobilne uređaje. ${ }^{29}$

25 Becker, D. A.; I. Bonadie-Joseph; J. Cain. Developing and completing a library mobile technology survey to create a user-centered mobile presence. // Library Hi Tech 31, 4(2013), 688-99. [citirano: 2019-9-10]. Dostupno na: https://doi.org/10.1108/LHT-03-2013-0032.

26 Ballard, T. L.; A. Blaine. A library in the palm of your hand.// New Library World 114, 5/6(2013), 251-58. [citirano: 2019-9-10]. Dostupno na: https://doi.org/10.1108/03074801311326876; Bridges, L.; H. G. Rempel; K. Griggs. Making the case for a fully mobile library web site: from floor maps to the catalog. // Reference Services Review 38, 2(2010), 309-20. [citirano: 2019-9-10]. Dostupno na: https://doi.org/10.1108/00907321011045061; također, Bomhold, C. Mobile services at academic libraries: meeting the users' needs? // Library Hi Tech 32, 2(2014), 336-45. [citirano: 2019-9-10]. Dostupno na: https://doi.org/10.1108/LHT-10-2013-0138.

${ }_{27} \mathrm{Kim}, \mathrm{B}$. The present and future of the library mobile experience. // Library Technology Reports 49, 6(2013), 15-28. [citirano: 2019-3-11]. Dostupno na: https://journals.ala.org/index.php/ ltr/article/view/4506; Kumar, A. Students opinion about the success of mobile technology in libraries: a case study of Jawaharlal Nehru University (JNU), New Delhi. // New Library World 115, 9/10(2014), 471-81. [citirano: 2019-10-17]. Dostupno na: https://doi.org/10.1108/NLW-10-20130075; također, Pažur, I. Attitude of the Rudjer Boškovic Institute's scientists to the small screen mobile devices library services: a user survey. // Library Hi Tech 32, 4(2014), 628-44. [citirano: 2019-10-17]. Dostupno na: https://doi.org/10.1108/LHT-03-2014-0025.

28 Caperon, L. Developing adaptable, efficient mobile library services: librarians as enablers. // Ariadne: web magazine for information professionals, 2015. [citirano: 2018-9-23]. Dostupno na: http://www.ariadne.ac.uk/issue73/caperon.

${ }_{29}$ Aldrich, A. Universities and libraries move to the mobile web. // Educause Review, 2010. [citirano: 2018-4-11]. Dostupno na: https:/er.educause.edu/articles/2010/6/universities-and-li- 
Mišljenje knjižničara varira, no ako smatraju da su knjižnični izvori i usluge za mobilne uređaje jednostavni za korištenje i da bi mogli unaprijediti knjižnično poslovanje, spremni su ih ponuditi. ${ }^{30}$ Posljednjih godina sve veći broj knjižnica ima neki vid izvora i usluga za mobilne uređaje; uz prilagođene mrežne stranice i priručne informacije (radno vrijeme, kontakt, lokacija) najčešće se nudi knjižnični katalog, baze znanstvenih informacija i podataka, zatim mrežne referentne usluge putem tekstualnih poruka, pristup korisničkom računu (rezervacije, produljenje posudbe, opomene), a od ostalih usluga javljaju se i elektroničke knjige, QR-kodovi, aplikacije za mobilne uređaje, međuknjižnična posudba, rezervacije opreme. ${ }^{31}$ Razvijanje aplikacija za mobilne uređaje za knjižnice predstavlja poseban izazov, no zbog troškova razvoja i održavanja te potrebnih posebnih znanja većina knjižnica odlučuje se za komercijalna rješenja koja razvija treća strana ${ }^{32}$, a iz istih se razloga radije odlučuju za prilagodbu mrežnih stanica. ${ }^{33}$

Unatoč preprekama, nedoumicama i dodatnim naporima sve veći broj knjižnica nastoji osigurati i prilagoditi svoje izvore i usluge korisnicima mobilnih uređaja te je za očekivati daljnje kretanje u tom pravcu, posebno u vidu responzivnih knjižničnih mrežnih stranica i korisničkih sučelja izvora i usluga. U tom smjeru svakako idu očekivanja i navike korisnika, kao što primjerice pokazuje statistika pristupa knjižničnom mrežnom mjestu Centra za znanstvene informacije Instituta Ruđer Bošković koja bilježi 28 \% pristupa s mobilnih uređaja. ${ }^{34}$

Premda su mnoge visokoškolske knjižnice rano, oko 2010. godine, počele razvijati usluge za mobilne uređaje, dio visokoškolskih knjižnica još ih nije

braries-move-to-the-mobile-web; Cowell, A. E.; M. Jia. Doing research on mobile devices: an undergraduate case study. // College and Undergraduate Libraries 23, 4(2016), 414-26. [citirano: 2019-10-17]. Dostupno na: https://doi.org/10.1080/10691316.2015.1025938; Rempel, H. G.; L. Bridges. That was then, this is now: replacing the mobile-optimized site with responsive design. // Information Technology and Libraries 32, 4(2013), 8-24. [citirano: 2019-10-15]. Dostupno na: https://doi.org/10.6017/ital.v32i4.4636 ; također, Karim, N. S. A.; S. H. Darus; R. Hussin. Mobile phone applications in academic library services: a students' feedback survey. // Campus-Wide Information Systems 23, 1(2006), 35-51. [citirano: 2019-10-15]. Dostupno na: https://oi. org/10.1108/10650740610639723.

30 Aharony, N. Librarians' attitudes towards mobile services. // Aslib Proceedings 65, 4(2013), 358-75. [citirano: 2019-10-15]. Dostupno na: https://doi.org/10.1108/AP-07-2012-0059.

31 Liu, Q. Y.; S. Briggs. Nav. dj.; Ashford, R.; L. Zeigen. Mobile technology in libraries survey: academic libraries, 2012. [citirano: 2019-9-10]. Dostupno na: http://educationdocbox. com/Distance_Learning/74704001-Mobile-technology-in-libraries-survey-conducted-january-2012-by-robin-ashford-george-fox-university-and-laura-zeigen-ohsu-academic-libraries. html; također, Bomhold, C. Nav. dj.

32 Tvrtka Boopsie za knjižnice razvija aplikacije za mobilne uređaje prema specifikacijama knjižnice.

33 Kim, B. Nav. dj.; Zhao, Y.; S. Deng; R. Zhou. Understanding mobile library apps continuance usage in China: a theoretical framework and empirical study. // Libri 65, 3(2015), 161-73. [citirano: 2019-10-15]. Dostupno na https://doi.org/10.1515/libri-2014-0148.

34 Podaci o pristupu knjižničnom mrežnom mjestu prikupljaju se i analiziraju na platformi Piwik http://lib.irb.hr/webstat/. Podaci su za razdoblje od prosinca 2017. do prosinca 2018. godine. 
razvijao niti ih je imao u planu ponuditi. Glavni su razlozi najčešće financijski troškovi, nedostatak vremena i kompetencija. ${ }^{35} \mathrm{U}$ razdoblju od 2010. do 2013. knjižnice intenzivnije rade na približavanju korisnicima mobilnih uređaja te broj mobilnih izvora i usluga raste (primjerice na mrežnoj stranici M-Libraries page, Library success Wiki, u tom je razdoblju zabilježen porast od $225 \%$ knjižnica koje nude mrežne stranice i/ili knjižnični katalog prilagođen za pristup s mobilnih uređaja). ${ }^{36}$ Istraživanje provedeno 2010 . u SAD-u pokazalo je da čak $44 \%$ visokoškolskih knjižnica nudi neki oblik usluga za mobilne uređaje (39 \% visokoškolskih knjižnica imalo je mrežne stranice prilagođene za pristup s mobilnih uređaja, a $36 \%$ prilagođeni knjižnični katalog, $31 \%$ SMS referentnu uslugu i $11 \%$ obavijesti putem tekstualnih poruka), a $21 \%$ ima u planu takve usluge u skoroj budućnosti, no $35 \%$ knjižnica nema takve planove. ${ }^{37}$ Prema istraživanju iz 2012. godine $52,7 \%$ visokoškolskih knjižnica na području sjeverozapadnog dijela SAD-a (savezne države Oregon, Washington i Idaho) prilagodilo je svoje mrežne stranice, a 48,6 \% prilagodilo je katalog za pristup s mobilnih uređaja, dok $31 \%$ nije imalo nijednu mobilnu uslugu ${ }^{38}$ Drugo istraživanje, također u SAD-u, iz 2013. pokazalo je da je 71,2 \% visokoškolskih knjižnica imalo neku vrstu pristupa prilagođenog za mobilne uređaje; od toga je 53,4 \% knjižnica imalo pristup knjižničnim izvorima i uslugama u okviru aplikacije sveučilišta za mobilne uređaje, a manje $(9,6 \%)$ se radilo o prilagođenom mrežnom mjestu..$^{39}$ Još jedno istraživanje iz 2013. pokazalo je da, iako dosta sveučilišnih knjižnica ima izvore i usluge prilagođene za mobilne uređaje $(71,2 \%)$, dosta uglednih sveučilišnih knjižnica i dalje ih nema (28,7\%). ${ }^{40}$ Analiza 50 sveučilišta u svijetu 2016. je pokazala da $30 \%$ knjižnica nudi aplikaciju za mobilne uređaje, a $84 \%$ nudi responzivna mrežna mjesta te da čak 88 \% sveučilišnih knjižnica nudi knjižnični katalog prilagođen za mobilne uređaje. Od ostalih usluga visoko su rangirani radno vrijeme, kontakt, pitanje knjižničaru i novosti. ${ }^{41}$

Knjižnični izvori i usluge za mobilne uređaje u prvom redu podrazumijevaju prilagodbu postojećih izvora i usluga u smislu pružanja kvalitetnog prikaza i navigacije. Knjižnice najčešće prvo prilagođavaju knjižnične mrežne stranice, a kasnije prilagođavaju ostale izvore i usluge, poglavito knjižnični katalog, dok pojedine knjižnice razvijaju i aplikacije za mobilne uređaje. Knjižnični izvori i usluge za

35 Carlucci Thomas, L. Gone mobile? (mobile libraries survey 2010). // Library Journal 135, 18(2010), 30-34. [citirano: 2019-10-17]. Dostupno na: https://eric.ed.gov/?id=EJ930803.

36 Kim, B. Nav. dj., str. 16.

37 Carlucci Thomas, L. Nav. dj.

38 Ashford, R.; L. Zeigen. Nav. dj., str. 2.

39 Bomhold, S. Nav. dj., str. 340.

40 Isto, str. 336.

${ }^{41}$ Pakdaman Naeini, M.; H. Sharif Moghaddam; S. Ziaei; A. Ghaebi. Mobile services in the libraries of the world's top universities. // Library Hi Tech. [citirano: 2019-10-17]. Dostupno na: https://doi.org/10.1108/LHT-07-2017-0140. 
mobilne uređaje mogu se podijeliti u nekoliko kategorija:42,43,44 1) mrežne stranice prilagođene za prikaz na mobilnim uređajima, 2) knjižnične aplikacije za mobilne uređaje, 3) knjižnični katalog za upotrebu na mobilnim uređajima (tzv. MOPAC), 4) baze znanstvenih informacija i podataka, 5) tekstualne poruke za komunikaciju, 6) društvene mreže i mediji, 7) nove tehnologije i usluge u knjižnicama.

\subsection{Mrežne stranice prilagođene za prikaz na mobilnim uređajima}

Kako bi mrežne stranice prilagođene za prikaz na mobilnim uređajima privukle i zadržale korisnike, moraju zadovoljavati određena načela prezentacije sadržaja pa je naglasak na jednostavnosti i dobroj navigaciji bez previše "klikanja". Responzivne mrežne stranice pojavljuju se 2010. godine ${ }^{45}$ i u posljednjih su nekoliko godina postale općeprihvaćeni standard u izradi mrežnih stranica za mobilne uređaje jer omogućavaju zadržavanje cjelokupnog sadržaja izvornih mrežnih stranica napravljenih za pregledavanje na velikom zaslonu računala, koji se restrukturira i reformatira prema različitim veličinama zaslona kako bi stranice bile pregledne i čitljive (slika 1). Postoje i optimalizirane mrežne stranice koje se sve više napuštaju jer zahtijevaju održavanje zasebnog prilagođenog mrežnog mjesta na kojem je samo dio sadržaja s izvornog mrežnog mjesta. Još su raširene i kompatibilne mrežne stranice koje nisu posebno prilagođene mobilnim uređajima, ali je njihov prikaz prihvatljiv i na malom zaslonu. Kompatibilne su stranice zbog previše sadržaja često nepregledne, predviđena je navigacija mišem pa je potrebno puno vertikalnog i horizontalnog pomicanja, a poveznice su sitne pa je prstom teško na njih "kliknuti" (slika 2). Bolju preglednost i navigaciju omogućavaju preglednici na mobilnim uređajima koji već imaju ugrađene opcije za prikaz kompatibilnih stranica pa se kod nekih automatski povećava tekst poveznice kako bi se prstom lakše "kliknulo". ${ }^{46,47}$ Budući da je mobilni pristup internetu u stalnom rastu, kod planiranja izgradnje mrežnog mjesta u prvi se plan sve više stavljaju mrežne stranice za mobilne uređaje. ${ }^{48}$

42 Meier, A. Comparative analysis: mobile device user research, 2010. [citirano: 2019-9-10]. Dostupno na: https://confluence.ucop.edu/display/CMDUR/Comparative+Analysis.

43 M-Libraries - library success: a best practices wiki. [citirano: 2019-9-10]. Dostupno na: https:// infopeople.org/sites/default/files/webinar/2011/10-12-2011/M-Libraries_wiki.pdf.

44 Liu, Q. Y.; S. Briggs. Nav. dj.

45 Rempel H. G.; L. Bridges. Nav. dj.

46 Lyerly, T. Mobile-fiendly vs mobile-optimization vs responsive design for websites. // Torspark, c 2016. [citirano: 2018-8-17]. Dostupno na: http://torspark.com/mobile-friendly-vs-mobile-optimized-vs-responsive-design/.

47 McAuliffe, J. Mobile compatible vs. mobile optimized - what's the difference? // Leonardo (blog), 2012. [citirano: 2018-8-11]. Dostupno na: http://blog.leonardo.com/mobile-compatible-vs-mobile-optimized-whats-the-difference/.

48 Grey, A.; R. Isaac-Menard. Database mobile accessibility assessment at Adelphi University Libraries. // Journal of Web Librarianship 9, 2/3(2015), 85-98. [citirano: 2019-9-12]. Dostupno 


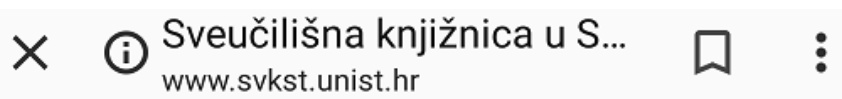
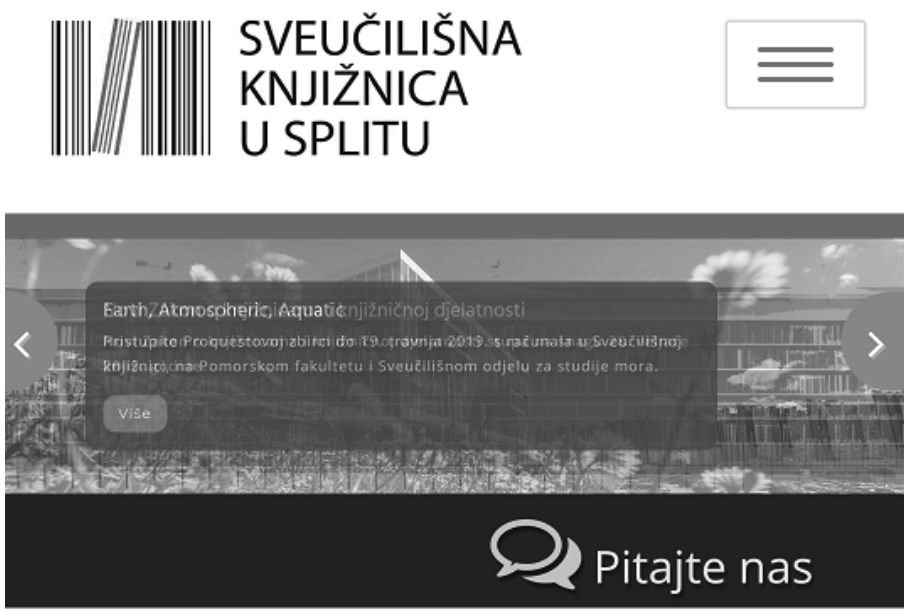

\section{Kalendar događanja}

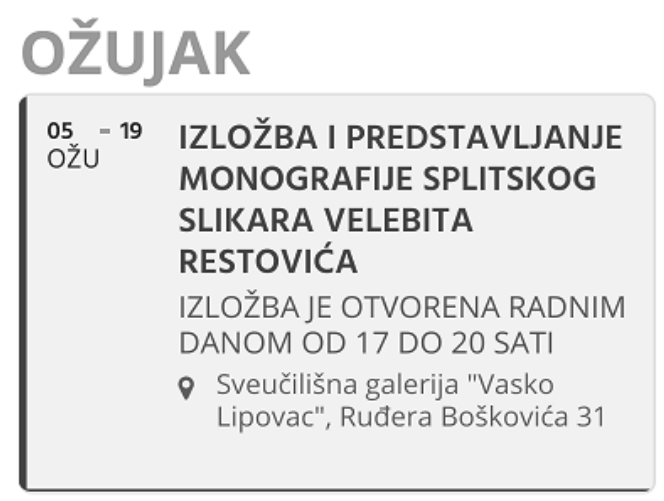

Slika 1. Sveučilišna knjižnica u Splitu, responzivne mrežne stranice

na: https://doi.org/10.1080/19322909.2015.1050567. 


\section{$\times$ A Naslovnica \\ https://www.svkri.uniri.hr}

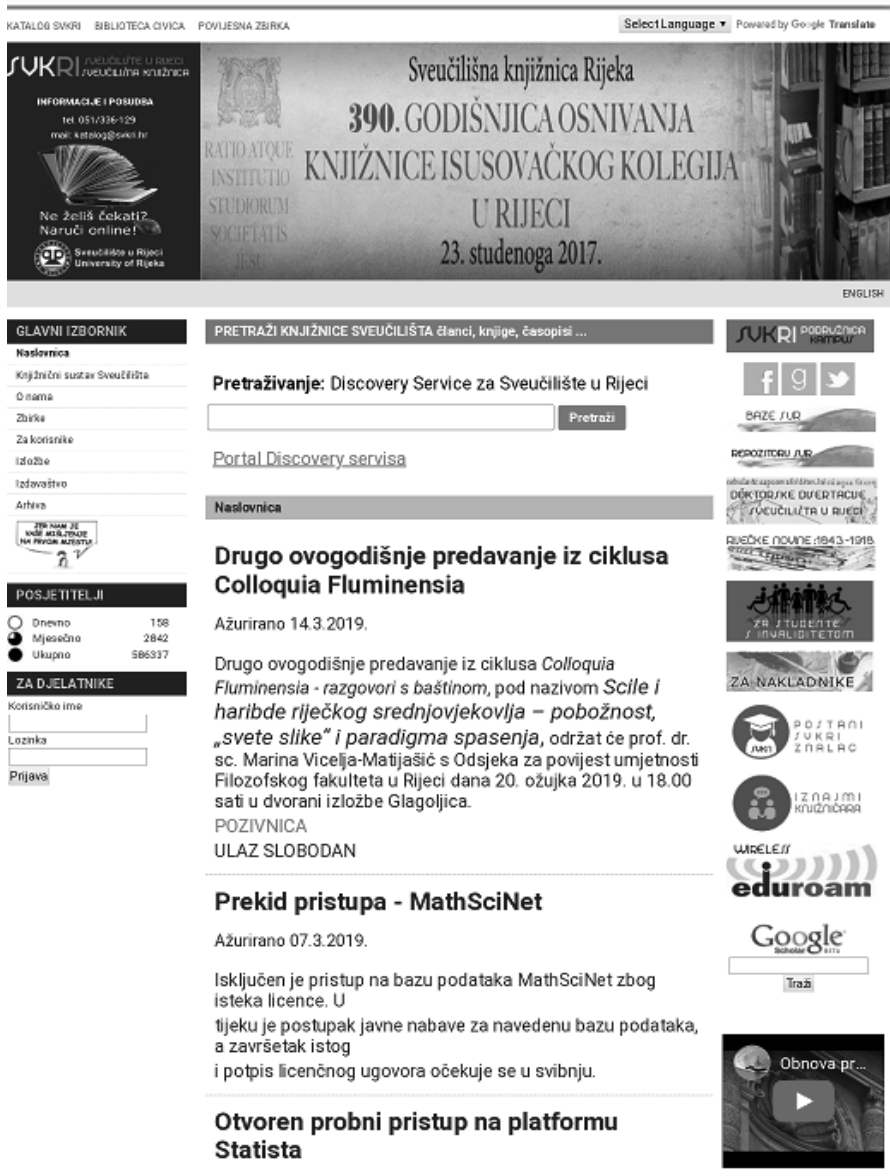

Ažurirano 28.22019

Otvoren je probni pristup na platformu Statista. Platforma

okuplia nacionalne i medunarodne statistike i podatke

tržištu s pristupom na više od 1.5 milijuna statistika,

prognoza, dosjea, izvještaja i infografika, $u$ okviru 80.000

razlic̄itih tema i 170 multidisciplinarnih kategorija.

Detaljniji opis platforme na hrvatskom jeziku dostupan

je ovdje i ovdje.

Probni pristup otvoren je do 31. svibnja 2019

Prvo predavanje iz trećeg ciklusa

"Colloquia Fluminensia"

Ažurirano 20.22019.

Prvo ovogodišnje predavanje iz trećeg ciklusa predavanja

Slika 2. Sveučilišna knjižnica u Rijeci, kompatibilne mrežne stranice 


\subsection{Knjižnične aplikacije za mobilne uređaje}

Knjižnična aplikacija za mobilne uređaje podrazumijeva aplikaciju razvijenu prema potrebama knjižnice, a može se raditi o samostalnom razvoju unutar matične ustanove/knjižnice ili ju prema zahtjevima knjižničara razvija treća strana. Kod knjižničnih aplikacija za mobilne uređaje razlikujemo (1) aplikacije za korištenje knjižničnih izvora i usluga te (2) aplikacije specijalnih knjižničnih zbirki. Potonje većinom razvijaju nacionalne knjižnice i knjižnice s rijetkom i vrijednom građom. Knjižnične aplikacije za korištenje knjižničnih izvora i usluga na mobilnim uređajima korisnicima obavezno pružaju važne informacije o knjižnici (kontakt, radno vrijeme, lokacija, događanja), omogućavaju pristup glavnim knjižničnim izvorima (poglavito knjižničnom katalogu) te pristup korisničkom računu, no mnoge nude i napredne mogućnosti kao što su provjera dostupnosti računala za rad, primanje poruka o roku vraćanja posuđene građe, pretraživanje pomoću skeniranja ISBN-barkoda, 3D-informacije o lokaciji građe u knjižnici, vodstvo do građe na polici pomoću Bluetootha i sl. Razvijanje knjižničnih aplikacija za mobilne uređaje dugotrajno je, iziskuje dodatne troškove te posebna znanja i vještine, a s obzirom na to da su za krajnje korisnike većinom besplatne, knjižnicama ne osiguravaju povrat investicije.

\subsection{Knjižnični katalog za upotrebu na mobilnim uređajima}

Razvijanje sučelja knjižničnog kataloga za upotrebu na mobilnim uređajima (engl. tzv. Mobile OPAC ili MOPAC) zahtjevan je zadatak, pa ga mnogi knjižnični katalozi nisu nudili čak do 2010. godine ${ }^{49}$, no posljednjih godina ono postaje prioritet. Uglavnom se koriste komercijalna programska rješenja (primjerice Boopsie, Library anywhere, AirPAC), ali sučelje prilagođeno mobilnim uređajima nude i nekomercijalni integrirani knjižnični sustavi (npr. Koha) (slika 3). Knjižnični katalog za upotrebu na mobilnim uređajima nudi jednostavnije opcije i uglavnom samo osnovno pretraživanje te mogućnost provjere korisničkog računa (dobivanje obavijesti o roku posudbe i dostupnosti građe) što je korisnicima osobito važno. Što se tiče aplikacije knjižničnog kataloga za mobilne uređaje, najviše knjižnica nudi pretraživanje kataloga u okviru svoje aplikacije knjižničnih izvora i usluga, a rjeđe za katalog razvijaju samostalnu aplikaciju..$^{50}$

\footnotetext{
49 Kim, B. Nav. dj.

50 Bridges, L.; H. G. Rempel; K. Griggs. Nav. dj.; također, Murray, L. Libraries 'like to move it, move it.'. // Reference Services Review 38, 2(2010), 233-49. [citirano: 2019-10-17]. Dostupno na: https://doi.org/10.1108/00907321011045007.
} 


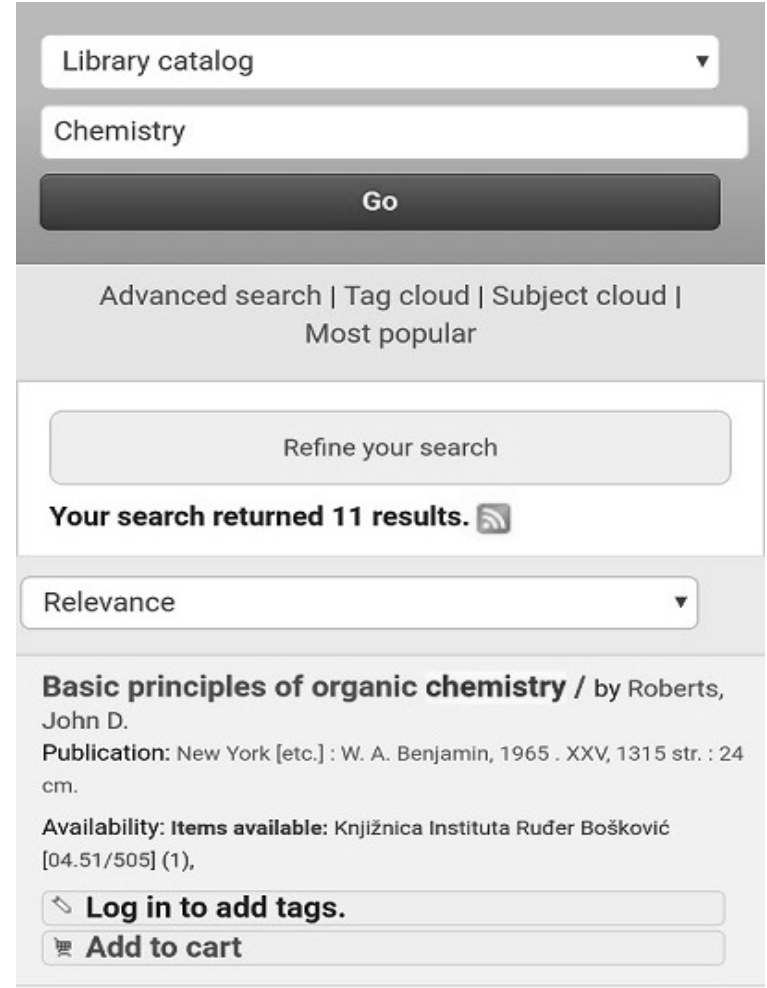

Modern organic chemistry / by Roberts, John D.

Publication: New York ; Amsterdam : W. A. Benjamin, 1967 . xxi, 844 str. : $26 \mathrm{~cm}$.

Availability: Items available: Knjižnica Instituta Ruđer Bošković [04.51/149] (1),

\section{Add to cart}

Supplement for modern organic chemistry / by

Slika 3. Koha - sučelje kataloga prilagođeno za mobilne uređaje

\subsection{Baze znanstvenih informacija i podataka}

Komercijalni su izdavači i dobavljači prije knjižnica počeli prilagođavati svoje platforme za pristup s mobilnih uređaja ${ }^{51}$, no zbog složenosti sadržaja baza znanstvenih informacija i podataka 2013./2014. primjerice tek je $28 \%$ baza imalo su-

51 Little, G. Keeping moving: smartphone and mobile technologies in the academic library. // Journal of Academic Librarianship, 37, 3(2011), 267-269. [citirano: 2019-10-17]. Dostupno na: https://doi.org/10.1016/j.acalib.2011.03.004. 
čelje prilagođeno za prikaz na mobilnim uređajima. ${ }^{52}$ Danas je njihov broj znatno veći pa je već prema analizi 2016. godine ${ }^{53}$ čak $67 \%$ baza bilo prilagođeno za pristup s mobilnih uređaja. ${ }^{54}$ Pojedini su izdavači također razvili i aplikacije za mobilne uređaje za svoje baze znanstvenih informacija i podataka, ali i za pojedinačne naslove znanstvenih časopisa te ih oglašavaju na svojim stranicama uobičajenim ikonama za Google Play i App Store mrežne trgovine aplikacija za mobilne uređaje gdje se mogu, uglavnom besplatno, preuzeti.

\subsection{Tekstualne poruke za komunikaciju}

Knjižničari koriste raznovrsne tekstualne poruke za komunikaciju s korisnicima: SMS-poruke, tekstualne poruke koje se putem mreže razmjenjuju u stvarnom vremenu - tzv. pričaonica (engl. chat) i trenutne poruke (engl. Instant Messages - IM), a pojedine su knjižnice počele ispitivati i mogućnosti videokomunikacije (npr. Skype).$^{55}$ Korisnicima se šalju i automatski generirane tekstualne poruke, najčešce putem integriranih knjižničnih sustava, koje su poglavito vezane za cirkulaciju građe (rezervacije i sl.) ili ih šalju drugi knjižnični sustavi, npr. poruke vezane uz rezervaciju opreme ili sobe za učenje, prijavu na seminar i sl. Vrlo je korisna opcija pošalji mi ovu informaciju (engl. text me this information) uz rezultate pretraživanja u knjižničnom katalogu koja omogućava primanje tekstualne poruke sa signaturom naslova na mobilni uređaj što pomaže kod traženja građe na polici. ${ }^{56}$ Tekstualne poruke uglavnom služe kao potpora virtualne referentne usluge (mnoge knjižnice u novije vrijeme za to koriste i trenutno jako popularne softvere WhatsApp ili Viber), za obavještavanje i promociju knjižničnih usluga te stvaranje zajednica korisnika i širu interakciju s njima. ${ }^{57}$

52 Grey, A.; R. Isaac-Menard. Nav. dj.

53 Ukupno je analizirano 39 baza znanstvenih informacija i podataka kojima je autorica imala pristup tijekom 2016. godine. Pojedine baze bile su dostupne na istoj platformi, pa je u tom slučaju $59 \%$ njih bilo prilagođeno za pristup s mobilnih uređaja.

${ }_{54}$ Pažur, I. Komunikacijski. Nav. dj.

55 Barnhart, F. D.; J. E. Pierce. Becoming mobile: reference in the ubiquitous library. // Journal of Library Administration 52, 6/7(2012), 559-570. [citirano: 2019-9-10]. Dostupno na: https://doi. org/10.1080/01930826.2011.556942 ; također, Little, G. Nav. dj.

56 Meier, A. Nav. dj.; također, McCarthy, G.; S. Wilson. ISBN and QR barcode scanning mobile app for libraries. // The Code4Lib Journal, 13 (2011). [citirano: 2018-11-25]. Dostupno i na: http://journal.code4lib.org/articles/5014.

57 Ansari, M. S. Using WhatsApp for service providing in libraries and information centres. // Knowledge Librarian 3, 2(2016), 57-63. [citirano: 2018-4-11]. Dostupno na: http://www.klibjlis. com/3.1.8.pdf.; također, Pun, R. WeChat in the library: promoting a new virtual reference service using a mobile app. // Library Hi Tech News 32, 6 (2015), 9-11. [citirano: 2019-10-15]. Dostupno na: https://doi.org/10.1108/LHTN-03-2015-0017. 


\subsection{Društvene mreže i mediji}

Mobilno društveno umrežavanje ubraja se u najpopularnije aktivnosti na mobilnim uređajima i na njega korisnici troše najviše vremena. ${ }^{58}$ Društvene su mreže uz sučelja prilagođena za pristup s mobilnih uređaja razvile i aplikacije za mobilne uređaje namijenjene prvenstveno komunikaciji tekstualnim porukama koje su među najkorištenijim aplikacijama (naročito Facebook Messenger). Facebook je najpopularnija društvena mreža u svijetu s gotovo 2 milijarde aktivnih korisnika, a najveći broj (95\%) za pristup koristi pametni telefon i tablet. ${ }^{59}$ Ostale trenutno popularne mobilne društvene platforme jesu Instagram, Youtube, Snapchat, Pinterest, Tumblr, Vine, Twitter. Društvene mreže pokazale su se kao vrlo dinamičan medij koji omogućava brzo objavljivanje i razmjenu sadržaja, kao i interakciju s drugim osobama. Knjižnice su prepoznale njihov informacijsko-komunikacijski potencijal te su ih prihvatile i upotrebljavaju ih u svrhu promocije događanja, knjižničnih izvora i usluga, korisnih informacija i u manjoj mjeri kao alat za interakciju s korisnicima koji uglavnom pasivno prihvaćaju objavljene sadržaje, koristeći opciju „sviđanja” (engl. like), manji broj razmjenjuje sadržaj, a rijetko javno komentiraju objave ili s knjižnicom komuniciraju putem privatnih poruka. ${ }^{60}$

\subsection{Nove tehnologije i usluge u knjižnicama}

Uvođenje novih tehnologija i usluga svojstveno je knjižnicama koje rade na unapređivanju svog poslovanja i približavanju novim potrebama korisnika koji ih, ako uvide njihovu korisnost i jednostavnost, usvajaju i u kontekstu knjižnice. Za mobilne su uređaje specifične tzv. lokacijske usluge (engl. Location-Based Servi$c e-L B S$ ), odnosno usluge koje se korisniku nude s obzirom na njegovu trenutnu lokaciju koju mobilni uređaj automatski otkriva.

Nove tehnologije i usluge koje se u različitoj mjeri primjenjuju u knjižnicama jesu: (1) kodovi za brzi pristup (engl. Quick Response - QR-kodovi), (2) komuni-

\footnotetext{
58 Mobile social media. // Statista. [citirano: 2018-11-25]. Dostupno na: https://www.statista. com/topics/2478/mobile-social-networks/.

59 Digital in 2018: global overview. Nav. dj.

60 Hebrang Grgić, I.; D. Mučnjak. Social networking phenomenon and its use in libraries. // Croatian Journal of Education 17, 1(2015), 217-241. [citirano: 2019-3-11]. Dostupno na: https://hrcak.srce.hr/137849; Pažur, I. Knjižnica Instituta Ruđer Bošković na društvenim mrežama. // Zbornik radova / 12. okrugli stol o slobodnom pristupu informacijama / urednici Ana Barbarić, Dorja Mučnjak. Zagreb : Hrvatsko knjižničarsko društvo, 2013. Str. 92-109.; također, Pažur, I. Hrvatske knjižnice na društvenoj mreži Facebook. // 13. seminar Arhivi, knjižnice, muzeji: mogućnosti suradnje u okruženju globalne informacijske infrastrukture. Zagreb: Hrvatsko knjižničarsko društvo, 2010. str. 260-77. [citirano: 2019-8-10]. Dostupno i na: http://fulir.irb.hr/id/eprint/480.
} 
kacija bliskog polja (engl. Near Field Communication - NFC), (3) Beacon-tehnologija i (4) proširena stvarnost (engl. Augmented reality - AR).

QR-kod može pohraniti razne informacije, a njegova je prednost što ga se jednostavno i besplatno može generirati na pojedinim mrežnim mjestima. Često služi kao nositelj adrese mrežne stranice, ali može pohraniti i bilo koji tekst, SMS-poruku, broj telefona, kontakt-podatke. Do pohranjene informacije dolazi se fotografiranjem koda pomoću kamere na mobilnom uređaju, a aplikacija očitava njezin sadržaj. ${ }^{61}$

Komunikacija bliskog polja (NFC) omogućava razmjenu različitih vrsta podataka uz pomoć kratkodometne bežične tehnologije dodirom ili približavanjem dvaju objekata s oznakama (engl. tag). Primjenjuje se kod cirkulacije građe, odnosno korisnici građu mogu zadužiti na polici dodirom NFC-oznake pomoću pametnog telefona. NFC-oznake mogu voditi iz knjiga na relevantne baze informacija i podataka ili na e-knjige; mogu služiti kao nositelji promocijskih materijala $\mathrm{s}$ informacijama o radnom vremenu, događanjima, s planom zgrade ili sadržavati poveznicu na knjižničnu aplikaciju za mobilne uređaje, a promotivni materijali s NFC-om mogu poticati gledatelje na doticaj s knjižničnim sadržajima i izvan same zgrade knjižnice, kao i na brzu razmjenu informacija o knjižničnim izvorima i uslugama putem društvenih mreža. Dodavanje oznaka u fizičke primjerke knjige omogućava i povezivanje s popratnim digitalnim materijalima (npr. s komentarima pisca, glazbenom podlogom, ocjenama knjiga, formatima citiranja, biografijom autora i sl.). ${ }^{62}$ Mogućnosti ove tehnologije tek se ispituju u knjižnicama pa ostaje za vidjeti hoće li zaživjeti i naći širu primjenu.

Beacon-tehnologiju razvio je Apple 2013. godine za pružanje lokacijskih usluga, tj. korisnicima se prema njihovoj lokaciji na mobilni uređaj odašilju ciljane automatske poruke pomoću Bluetooth-tehnologije. ${ }^{63}$ Beacon-prijenosnici naročito se koriste u maloprodaji, ali su ih pojedine knjižnice uvele kao alat za promociju svojih usluga. Ovisno o lokaciji korisnika u knjižnici ili čak u njezinoj neposrednoj blizini, Beacon-prijenosnici šalju na pametni telefon dojave o knjižničnim izvo-

${ }^{61}$ McCarthy G.; S. Wilson. Nav. dj.; također, Mishra, A. S.; S. Kumar Umre; P. Kumar Gupta. Qr code In library practice some examples. // International journal of engineering sciences \& research technology 6,2(2017), 319-26. [citirano: 2019-10-17]. Dostupno na: http://www.ijesrt. com/issues\%20pdf\%20file/Archive-2017/February-217/47.pdf.

${ }_{62}$ McHugh, S.; K. Yarmey. Near field communication: recent developments and library implications. // Synthesis Lectures on Emerging Trends in Librarianship 1, 1(2014), 1-93. [citirano: 2019-10-17]. Dostupno na: https://doi.org/10.2200/S00570ED1V01Y201403ETL002; također, Yusof, M. K.; A. Abel; M. Y. Saman; M. N. Abdul Rahman. Adoption of near field communication in S-Library application for information science. // New Library World 116, 11/12(2015), 728-47. [citirano: 2019-10-15]. Dostupno na: https://doi.org/10.1108/NLW-02-2015-0014.

63 Novak, S. IBeacon - od buzzworda do realnog iskustva. // Plan B. [citirano: 2018-10-24]. Dostupno na: http://planb.hr/ibeacon-od-buzzworda-do-realnog-iskustva/. 
rima i uslugama. Za primanje poruke dovoljno je na mobilnom uređaju aktivirati opciju Bluetooth i biti u dometu uređaja Beacon. ${ }^{64}$

Posljednjih nekoliko godina u središte interesa dolazi proširena stvarnost koja statični prostor pretvara u dinamični kombinacijom virtualnoga i stvarnoga, a mijenja se s korisnikovom lokacijom i podrazumijeva njegovo aktivno sudjelovanje. Stvarni se okoliš ne zamjenjuje, već se dopunjava digitalnim objektima i po tome se proširena stvarnost razlikuje od virtualne. ${ }^{65}$ Proširena stvarnost $u$ knjižnici može poslužiti za orijentaciju u samoj zgradi ili kod traženja građe na polici, može pružati dodatne informacije o građi na polici pomoću aplikacija za prepoznavanje (engl. recognition applications) ili se može koristiti kao pomoć knjižničarima u sortiranju knjiga, za poboljšanje knjižničnih uputa, rekonstrukciju i obnovu artefakata, a primjena je moguća i kod podučavanja informacijske pismenosti. ${ }^{66}$ Knjižnične aplikacije za mobilne uređaje bazirane na proširenoj stvarnosti razvijaju se i testiraju tek od sredine 2012 . godine $^{67}$, no premda pojedine knjižnice iskušavaju mogućnosti proširene stvarnosti, u praksi ona još nije značajnije zaživjela.

\section{Analiza sadržaja mrežnih stranica visokoškolskih i srodnih knjiž- nica}

\subsection{Metodologija, uzorak, istraživačka pitanja}

S ciljem utvrđivanja zastupljenosti knjižničnih izvora i usluga za pristup putem mobilnih uređaja postavljena su sljedeća istraživačka pitanja: 1) Koliko su se razmatrane visokoškolske i srodne knjižnice prilagodile korisnicima u smislu

64 Bess, M.; S. K. Wu; B. Price. 49er alerts: utilizing mobile marketing technology for library outreach. // Public Services Quarterly 11, 4(2015), 291-99. [citirano: 2019-9-10]. Dostupno na: https://doi.org/10.1080/15228959.2015.1088816 ; također, Eng, S. Connection, not collection: using IBeacons to engage library users. // Computers in libraries 35, 10(2015), 13-16.

${ }^{65}$ Accart, J-P. Through the looking glass: envisioning new library technologies Augmented reality in the (real) library world - part one. // Library High Tech News 31, 1(2014). [citirano: 201910-15]. Dostupno na: https://doi.org/10.1108/LHTN-12-2013-0072.

${ }_{66}$ Massis, B. Using virtual and augmented reality in the library. // New Library World 116, 11/12(2015), 796-99. [citirano: 2019-10-17]. Dostupno na: https://doi.org/10.1108/NLW-082015-0054; Shatte, A.; J. Holdsworth; I. Lee. Mobile augmented reality based context-aware library management system. // Expert Systems with Applications 41, 5(2014), 2174-85. [citirano: 2019-10-15]. Dostupno na: https://doi.org/10.1016/j.eswa.2013.09.016; također, Zak, E. Do you believe in magic? Exploring the conceptualization of augmented reality and its implications for the user in the field of library and information science. // Information Technology and Libraries 33, 4(2014), 23-50. [citirano: 2019-10-15]. Dostupno na:https://doi.org/10.6017/ital.v33i4.5638 .

67 Hahn, J. Mobile augmented reality applications for library services. // New Library World 113, 9/10 (2012), 429-38. [citirano: 2019-9-12]. Dostupno na: https://doi. org/10.1108/03074801211273902. 
dostupnosti knjižničnih izvora i usluga za mobilne uređaje? 2) Koje su vrste knjižničnih izvora i usluga za mobilne uređaje u većoj, a koje u manjoj mjeri zastupljene u razmatranim visokoškolskim i srodnim knjižnicama? 3) Kakve su sličnosti i razlike između pojedinih kategorija razmatranih knjižnica s obzirom na implementiranost analiziranih knjižničnih izvora i usluga za mobilne uređaje?

U razdoblju od 12. prosinca 2018. do 12. veljače 2019. pregledana su mrežna mjesta 97 knjižnica, ${ }^{68}$ od kojih je 65 visokoškolskih knjižnica ${ }^{69}$ i 32 srodne knjižnice koje u Hrvatskoj podupiru znanstveni rad i visoko obrazovanje: Nacionalna i sveučilišna knjižnica u Zagrebu i druge sveučilišne knjižnice (6), općeznanstvene (6) i specijalne knjižnice - instituti i zavodi (20). Analiza sadržaja obuhvaća utvrđivanje zastupljenosti sedam vrsta knjižničnih izvora i usluga za mobilne uređaje kod knjižnica prema deset kriterija:

1. Mrežne stranice prilagođene za prikaz na mobilnim uređajima: 1) responzivne mrežne stranice, 2) opće upute i/ili informacije za mobilne korisnike (naziv mrežne stranice ili izbornika ili poveznica na mrežne stranice za mobilne uređaje)

2. Knjižnične aplikacije za mobilne uređaje: 1) poveznica i/ili opće informacije na knjižničnu aplikaciju za mobilne uređaje s mrežnih stranica knjižnice, 2) knjižnična aplikacija u Google Play mrežnoj trgovini aplikacija za mobilne uređaje ${ }^{70,71}$

3. Knjižnični katalog za upotrebu na mobilnim uređajima (MOPAC): 1) poveznica $\mathrm{i} / \mathrm{ili}$ opće informacije na aplikaciju kataloga za mobilne uređaje s mrežnih stranica knjižnice, 2) responzivno mrežno sučelje kataloga

4. Baze znanstvenih informacija i podataka: poveznica i/ili opće informacije na aplikacije komercijalnih baza, e-knjiga, e-časopisa za mobilne uređaje

5. Tekstualne poruke za komunikaciju: informacije i/ili poveznica na pričaonicu ili trenutne poruke, Viber, WhatsApp i sl.

6. Društvene mreže i mediji: knjižnični profil na društvenoj mreži Facebook

\footnotetext{
68 U uzorak istraživanja uključene su sve visokoškolske i srodne knjižnice popisane na mrežnoj stranici Knjižnice u Hrvatskoj http://lib.irb.hr/web/hr/knjiznice/itemlist/category/34-knjiznice_u_ hrvatskoj.html.

69 Knjižnice veleučilišta nisu obuhvaćene.

70 U Hrvatskoj na operativni sustav Android otpada 83 \% tržišta, stoga je pretražena samo mrežna trgovina Google Play.

71 Market share of mobile operating systems 2010-2018 Croatia. // Statista. [citirano: 20193-11]. Dostupno na: https://www.statista.com/statistics/669610/market-share-mobile-operating-systems-croatia/.
} 
7. Nove tehnologije i usluge u knjižnicama (QR, NFC, Beacon, AR): na mrežnoj stranici knjižnice ili spominjanje primjene takvih tehnologija u knjižnici.

Pregledavanje mrežnih stranica napravljeno je s malog zaslona pametnog telefona (5 inča), ali i s velikog zaslona na stolnom računalu jer takav pristup još uvijek prevladava pa bi korisnike koji pristupaju na taj način trebalo uputiti i na mogućnosti pristupa putem mobilnih uređaja.

Prisutnost svakog pojedinog kriterija analize sadržaja s manje ili jednako $50 \%$ smatrana je nedovoljnom zastupljenošću, odnosno ako je zastupljenost preko $50 \%$, može se zaključiti da je kriterij zastupljen kod većine razmatranih knjižnica i, u konačnici, da većina knjižnica nudi knjižnične izvore i usluge za mobilne uređaje.

\subsection{Rezultati analize sadržaja knjižničnih mrežnih mjesta}

Od ukupnog broja promatranih knjižnica (97), njih $43 \%$ ima prilagođene, responzivne mrežne stranice, dok 57 \% ima kompatibilne mrežne stranice koje se „u nuždi“ mogu koristiti, ali je s obzirom na sitan tekst sadržaja i poveznica teško snalaziti se na njima. Među knjižnicama s responzivnim mrežnim stranicama najbrojnije su visokoškolske knjižnice (64 \%), slijede instituti i zavodi (22 \%), općeznanstvene knjižnice (7\%) i sveučilišne knjižnice (7\%). Međutim ako se promotri prilagođenost knjižnica unutar njihove kategorije, responzivne mrežne stranice najzastupljenije su kod sveučilišnih i općeznanstvenih knjižnica (obje kategorije s po $50 \%$ ), slijede institutske i zavodske knjižnice ( $45 \%$ ), a najmanje su zastupljene među visokoškolskim knjižnicama (42\%), dakle u najbrojnijoj kategoriji knjižnica.

S obzirom na to da je kod ukupnog broja promatranih knjižnica zastupljenost rasponzivnih mrežnih stranica manja ili jednaka 50 \%, može se zaključiti da knjižnice u tom pogledu nisu dovoljno izišle u susret korisnicima mobilnih uređaja. Zastupljenost responzivnih mrežnih stranica manja je ili jednaka $50 \%$ čak i unutar svake pojedine kategorije knjižnica; kod sveučilišnih i općeznanstvenih knjižnica zastupljenost je kriterija na granici pa se ipak može govoriti o dobroj zastupljenosti.

Samo jedna knjižnica (Knjižnica Tekstilno-tehnološkog fakulteta) (1 \%) ima opću uputu i/ili informacije za korisnike mobilnih uređaja koja se direktno tiče pristupa u smislu povezivanja na bežičnu mrežu („Upute za spajanje mobilnih telefona"). Knjižnice u pravilima ponašanja na svojim mrežnim stranicama mobilne uređaje spominju jedino u kontekstu zabrane korištenja u čitaonicama, dok je veća naklonost prema prijenosnim računalima pa se ponegdje spominje mogućnost nji- 
hova donošenja i korištenja, iz čega se iščitava i mišljenje o njihovoj prikladnosti za studijski rad za razliku od mobilnih uređaja koji se prvenstveno smatraju ometajućim čimbenikom. Naziv mrežne stranice ili izbornika ili poveznicu na mrežne stranice prilagođene za mobilne uređaje nema nijedna knjižnica (poveznica na inačicu mrežnih stranica za mobilne uređaje postoji samo kod Digitalne zbirke Hrvatske akademije znanosti i umjetnosti). Iz navedenog je vidljiva zastupljenost ovog kriterija kod manje od $50 \%$ knjižnica.

Nijedna knjižnica nema na svojim mrežnim stranicama poveznicu i/ili opće informacije o knjižničnoj aplikaciji za mobilne uređaje. Pretragom mrežne trgovine Google Play jedino je pronađena aplikacija za mobilne uređaje „Pozdrav iz Zagreba - Greetings from Zagreb“ koju je razvila Nacionalna i sveučilišna knjižnica u Zagrebu 2017. godine, koja koristi fond njihove Grafičke zbirke, pa je u tom smislu aplikacija specijalne knjižnične zbirke. Iz navedenog je vidljivo da su oba kriterija vezana uz aplikaciju zastupljena s manje od $50 \%$.

Aplikaciju knjižničnog kataloga za mobilne uređaje nema nijedna knjižnica (ne postoji poveznica i/ili opće informacije s mrežnih stranica knjižnice), a samo $13 \%$ knjižnica nudi katalog s responzivnim mrežnim sučeljem. Najveći udio među njima imaju visokoškolske knjižnice (54 \%), instituti i zavodi (31 \%), 7,5 \% sveučilišne (Gradska i sveučilišna knjižnica u Osijeku) i 7,5 \% općeznanstvene knjižnice (Znanstvena knjižnica u Dubrovniku). Premda je udio visokoškolskih knjižnica najveći u ukupnom broju knjižnica, kada se knjižnice usporede po zastupljenosti unutar vlastite kategorije, na posljednjem su mjestu (11\%), a prednjače institutske i zavodske knjižnice ( $20 \%$ ) te sveučilišne i općeznanstvene (obje s po $17 \%$ ). Od programskih rješenja responzivno sučelje imaju Crolist (Vero), Koha i Zaki, dok Aleph, Crolist, Metelwin i ISIS nude kompatibilno sučelje koje je nespretno za pretraživanje. Oba parametra vezana uz mobilni katalog zastupljena su kod knjižnica s manje od $50 \%$, čak i kada se zastupljenost razmotri po kategorijama knjižnica.

Samo dvije knjižnice ( $2 \%$ ) korisnike upućuju na pristup putem mobilnih uređaja bazama znanstvenih informacija i podataka, e-knjigama ili e-časopisima dajući o tome informacije i poveznice. Knjižnica Ekonomskog fakulteta u Osijeku uz obavijest o probnom pristupu na EBSCO e-books spominje i aplikaciju za mobilne uređaje, a Centar za znanstvene informacije Ruđer Bošković uz popis institucijske pretplate elektroničkih časopisa nudi ikone s poveznicama na Google Play i App Store za preuzimanje aplikacija za mobilne uređaje ili uz naslov nudi napomenu o postojanju prilagođenih mrežnih stranica te se objavljuju novosti o mogućnostima pristupa putem mobilnih uređaja. Iz navedenoga je vidljiva zastupljenost tog kriterija kod razmatranih knjižnica ispod $50 \%$. 
Komunikacija s korisnicima pomoću tekstualnih poruka (pričaonica ili trenutne poruke) nije zaživjela i ne nudi ju nijedna knjižnica. Knjižnica Rudarsko-geološko-naftnog fakulteta o dospijeću rezervirane građe obavještava korisnike elektroničkom poštom ili mobilnim telefonom, što daje naslutiti da se možda radi o slanju SMS-poruke.

Pretraživanjem društvene mreže Facebook ${ }^{72}$ utvrđeno je da $23 \%$ knjižnica posjeduje profil na društvenoj mreži Facebook. Prema kategorijama knjižnica posjeduju ga sve sveučilišne knjižnice (100\%), slijede općeznanstvene (33 \%); od visokoškolskih knjižnica profil ima $18 \%$, a od instituta i zavoda ima ga samo 10 \% knjižnica. Premda je u ukupnom broju razmatranih knjižnica zastupljenost ovog kriterija ispod $50 \%$, ako se u obzir uzima zastupljenost po kategorijama knjižnica, sve razmatrane sveučilišne knjižnice zadovoljavaju kriterij zastupljenosti iznad $50 \%$.

Primjena novih tehnologija i usluga (QR, NFC, Beacon, AR) ne spominje se na većini mrežnih stranica razmatranih knjižnica, što ne znači da ih neke knjižnice ipak ne koriste. Knjižnica Hrvatske akademije znanosti i umjetnosti koristi QR-kodove u zapisima digitalnih zbirki (slika 4), a Nacionalna i sveučilišna knjižnica u Zagrebu pokrenula je 2018. godine projekt Smart Library - prototip primjene IoT tehnologije u knjižnici koji promiče primjenu novih tehnologija (5G, NB IoT, umjetnu inteligenciju, virtualnu ili proširenu stvarnost) pa se u okviru projekta radi i na uvođenju Beacon-tehnologije u prostor knjižnice. ${ }^{73}$

S obzirom na to da se nove tehnologije, prvenstveno NFC, Beacon i AR, tek uvode u knjižnicama razvijenijih zemalja ${ }^{74}$, vrlo je vjerojatno da ih većina razmatranih visokoškolskih i srodnih knjižnica još ne koristi te se unatoč navedenim pojedinačnim primjerima može zaključiti da nove tehnologije još nisu zastupljene.

\footnotetext{
72 Facebook je prema broju aktivnih korisnika u siječnju 2019. najpopularnija društvena mreža u svijetu, a slijedi Youtube; također, Global social networks ranked by number of users 2019. // Statista. [citirano: 2019-3-11]. Dostupno na: https://www.statista.com/statistics/272014/globalsocial-networks-ranked-by-number-of-users/.

73 Smart library: detaljan opis projekta. [citirano: 2019-10-15]. Dostupno na: https://www.generacijanext.hr/media/uploads/submissions/1fd74a17d00247bbb6eedc7d13d3cfe9/smart library_ detaljan_opis_projekta_2018.pdf.; također, Projekt NSK namijenjen razvoju pametnih k̄njižnica nagrađen u sklopu donacijskog natječaja Hrvatskog Telekoma „Generacija Next“, 2018. [citirano: 2019-10-15]. Dostupno na: http://www.nsk.hr/projekt-nsk-namijenjen-razvoju-pametnih-knjiznica-nagraden-u-sklopu-donacijskog-natjecaja-hrvatskog-telekoma-generacija-next/.

74 Liu, Q. Y.; S. Briggs. Nav. dj., str. 139.
} 


\section{(i) dizbi.hazu.hr/object/25523 \\ (3) :}

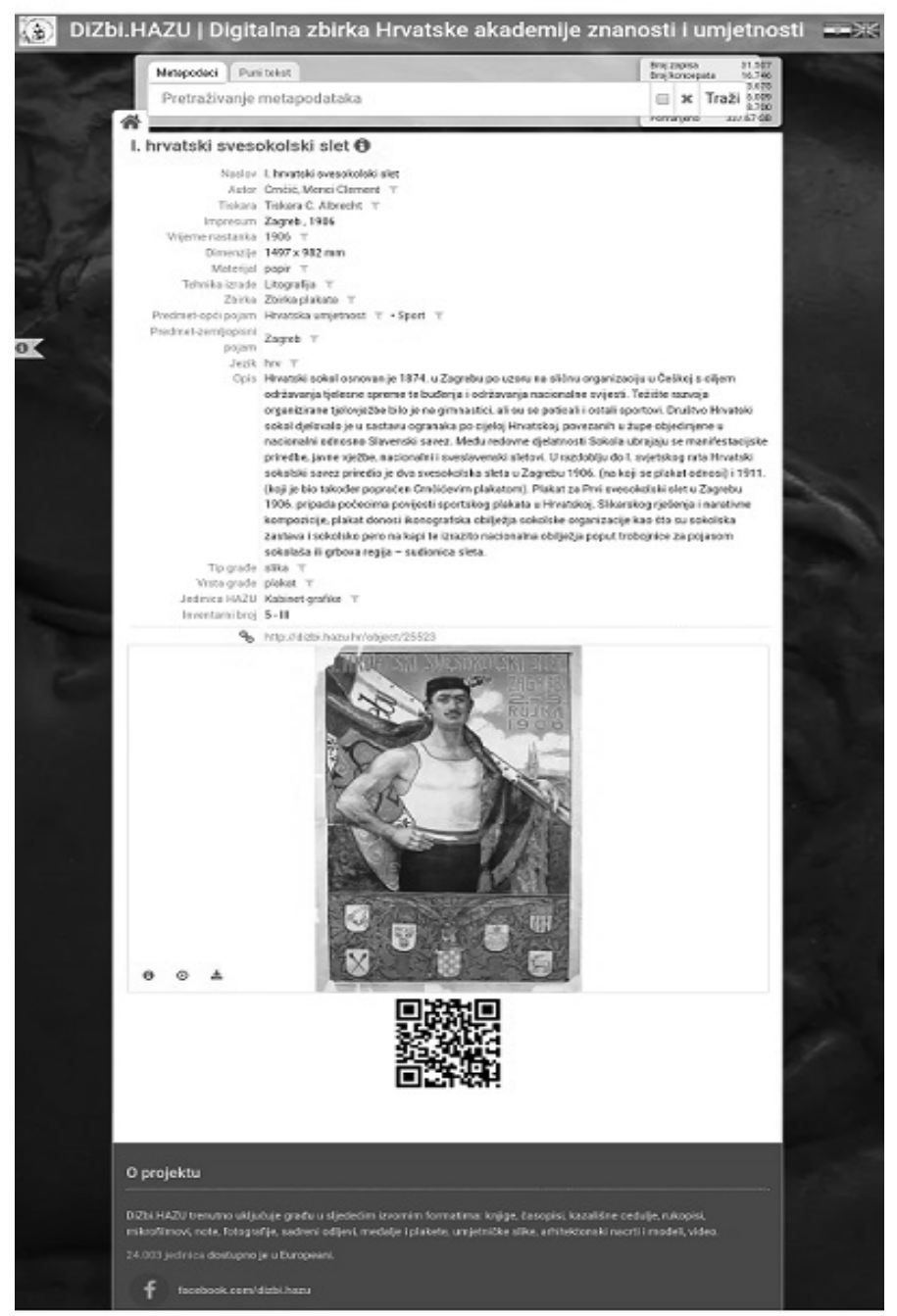

Slika 4. Digitalna zbirka HAZU - QR-kod u bibliografskom zapisu

Uz 10 glavnih kriterija razmotrena su i 2 dodatna kriterija važna za korisnike mobilnih uređaja i promociju/korištenje izvora i usluga za mobilne uređaje:

1) nudi li knjižnica objedinjeno pretraživanje svih dostupnih e-izvora, tzv. discovery search te 
2) provodi li knjižnica edukaciju o knjižničnim izvorima i uslugama za mobilne uređaje?

Za hrvatsku akademsku i znanstvenu zajednicu pretplaćen je EBSCO discovery search koji, osim što omogućava jednostavno pretraživanje svih baza znanstvenih informacija i podataka na jednom mjestu, ima responzivno sučelje pa je važan za mobilne korisnike i takvi se pretraživači zato obično nalaze na početnoj mrežnoj stranici knjižnice ili su uključeni u knjižničnu aplikaciju za mobilne uređaje. Ukupno 29 \% razmatranih knjižnica omogućava takvo pretraživanje: prema kategorijama knjižnica nude ga sve sveučilišne knjižnice (100 \%), 28 \% visokoškolskih knjižnica, $20 \%$ institutskih i zavodskih knjižnica, dok ga ne nudi nijedna općeznanstvena knjižnica. ${ }^{75} \mathrm{U}$ ukupnom broju knjižnica zastupljenost ovog kriterija je ispod $50 \%$, dok je unutar pojedinačnih kategorija samo kod sveučilišnih knjižnica zastupljen preko $50 \%$.

Edukaciju o knjižničnim izvorima i uslugama za mobilne uređaje eksplicitno na svojim mrežnim stranicama ne spominje nijedna knjižnica od njih ukupno 22 (18 \%) koje navode održavanje grupne ili individualne edukacije ili nude edukacijske materijale (npr. brošuru za online baze podataka). Uglavnom se spominje edukacija korisnika u smislu pretraživanja baza podataka i kataloga, no moguće je da se i u tom okviru spominju mogućnosti mobilnog pristupa. Nacionalna i sveučilišne knjižnice prednjače u edukaciji, održava ih svih 6 knjižnica (100 \%), slijede institutske i zavodske (20\%) te visokoškolske knjižnice (18 \%), dok općeznanstvene knjižnice ne navode edukacijske aktivnosti. Knjižnica Fakulteta za turistički i hotelski menadžment u Opatiji korisnicima je primjerice pripremila videovodiče za pretraživanje baza znanstvenih informacija i podataka. Knjižnice Filozofskog fakulteta u Rijeci i Filozofskog fakulteta u Zagrebu navode edukaciju vještina informacijske pismenosti koje možda uključuju i vještine potrebne za korištenje izvora i usluga za mobilne uređaje. Iz navedenog je vidljivo da edukaciju općenito provodi manje od $50 \%$ razmatranih knjižnica, stoga taj kriterij nije zastupljen, iako je u potpunosti zastupljen kod svih sveučilišnih knjižnica.

Prema prikupljenim podacima analize sadržaja knjižničnih mrežnih mjesta po svakom pojedinačnom kriteriju za ukupno 97 knjižnica, pokazuje se da su svi kriteriji zastupljeni s manje ili jednako $50 \%$; među njima ipak prednjače responzivne mrežne stranice, objedinjeno pretraživanje svih dostupnih e-izvora, profil na društvenoj mreži Facebook i katalog s responzivnim mrežnim sučeljem. Najmanje ili gotovo uopće nisu zastupljene knjižnične aplikacije za mobilne uređaje i aplikacija knjižničnog kataloga, nove tehnologije i usluge te komunikacija pomoću

\footnotetext{
75 Prema podacima na Portalu elektroničkih izvora za hrvatsku akademsku i znanstvenu (http:// baze.nsk.hr/ ) zajednicu neke su ustanove uključene u pretplatu na discovery search, no s obzirom na to da na njihovim mrežnim stranicama nije pronađena poveznica, postojanje te usluge nije za knjižnicu uzeto u obzir jer ju korisnici ne mogu pronaći i koristiti ako pristupaju s knjižničnog mrežnog mjesta.
} 
tekstualnih poruka, odnosno nisu zastupljene mogućnosti specifične za mobilne uređaje. To potvrđuje i nedostatak općih uputa i/ili informacija za mobilne korisnike, kao i informacija o pristupu putem mobilnih uređaja bazama znanstvenih informacija i podataka, e-knjigama ili e-časopisima.

Ako se razmatra zastupljenost kriterija po kategorijama knjižnica, zastupljenost u nekoliko slučajeva prelazi 50 \%: sve sveučilišne knjižnice imaju profil na društvenoj mreži Facebook i discovery search, (također sve održavaju i edukaciju, premda ona nužno ne uključuje edukaciju o knjižničnim izvorima i uslugama za mobilne uređaje), a na granici su sveučilišne i općeznanstvene knjižnice kod kojih su reponzivne mrežne stranice zastupljene s $50 \%$. Prema tome je vidljivo da visokoškolske knjižnice zapravo zaostaju u implementaciji knjižničnih izvora i usluga za mobilne uređaje.

Gledajući zastupljenost svih 10 kriterija po pojedinačnim knjižnicama, najveći broj (3, tj. $30 \%$ ) je zastupljen kod 8 knjižnica ${ }^{76}, 13$ knjižnica $20 \%$, a 33 knjižnica samo $10 \%$ kriterija, dok 43 knjižnice (44 \%) nemaju zadovoljen nijedan kriterij. $\mathrm{S}$ obzirom na to da nijedna knjižnica ne ispunjava više od $50 \%$ zadanih kriterija, može se zaključiti kako većina razmatranih knjižnica nema u dovoljnoj mjeri zastupljene knjižnične izvore i usluge za mobilne uređaje, kao i da zamjetan broj knjižnica još uopće ne nudi knjižnične izvore i usluge za mobilne uređaje.

Uzmu li se u obzir i 2 dodatna kriterija analize sadržaja, 4 knjižnice ${ }^{77}$ imaju 5 zastupljenih kriterija (42\%), 3 knjižnice zadovoljavaju 4 kriterija (33\%), 11 knjižnica 3 kriterija (25\%), 17 knjižnica zadovoljava 2 kriterija (17\%), 32 knjižnice samo 1 (8\%) kriterij, dok 30 knjižnica (31\%) nema zadovoljen nijedan kriterij. S obzirom na to da je i u ovom slučaju zastupljenost kriterija manja ili jednaka $50 \%$ (kao i da edukacija ne sadržava nužno i edukaciju o knjižničnim izvorima i uslugama za mobilne uređaje), potvrđuje se da većina razmatranih knjižnica nema u dovoljno mjeri implementirane knjižnične izvore i usluge za mobilne uređaje.

\section{Zaključak}

Mobilni uređaji utječu na način na koji korisnici traže informacije i pristupaju im, što je dovelo i do novih očekivanja u pristupu i korištenju knjižničnih izvora i usluga. Uvođenje tehnoloških novosti nije jednostavno, a knjižnice trebaju uložiti dodatni napor u njihovu svladavanju i najčešće su u tome prepuštene same sebi. S obzirom na to da je korištenje informacijsko-komunikacijske tehnologije nezaobilazno u suvremenom društvu, knjižnice se moraju prilagoditi i uključiti ju u pružanju svojih izvora i usluga sve više tehnološki orijentiranim generacijama korisnika.

76 Od toga je 1 knjižnica specijalna, 2 su sveučilišne, 2 općeznanstvene, a 3 visokoškolske knjižnice.

77 Od toga je 1 knjižnica specijalna, 1 je sveučilišna, a 2 su visokoškolske knjižnice. 
Visokoškolske i srodne knjižnice koje podupiru znanstveni rad i visoko obrazovanje trebale bi kao minimum prilagodbe korisnicima mobilnih uređaja ponuditi responzivne knjižnične mrežne stranice. Trenutna situacija razmatranim knjižnicama ne ide osobito u prilog jer, iako su responzivne mrežne stranice zastupljene (43\%), ipak ih nema više od polovine knjižnica. Premda bi visokoškolske knjižnice radi studenata trebale prednjačiti u prilagodbi mobilnim korisnicima, one unutar svoje kategorije ne premašuju polovinu ( $42 \%$ ), a u usporedbi s drugim kategorijama razmatranih knjižnica čak su po zastupljenosti responzivnih stranica posljednje. Knjižnični katalozi s responzivnim mrežnim sučeljem također su slabo zastupljeni, odnosno nema ga ni pola razmatranih knjižnica, a prema kategorijama knjižnica najslabije su zastupljeni kod visokoškolskih knjižnica (11\%).

S obzirom na opću ekspanziju responzivnih mrežnih stanica, može se reći da su responzivna knjižnična mrežna mjesta razmatranih knjižnica prvenstveno rezultat općeg tehnološkog napretka i novog trenda izrade mrežnih stranica, a ne posljedica strateškog promišljanja o pristupu putem mobilnih uređaja. Na to upućuje i slaba zastupljenost ostalih kriterija provedene analize sadržaja, iz čega je vidljivo da potrebe korisnika mobilnih uređaja općenito nisu uzete u obzir. Također nisu iskorištene ni postojeće mogućnosti pristupa putem mobilnih uređaja koje pružaju izvori i usluge komercijalnih izdavača jer se korisnici o tome ne obavještavaju (ne postoje opće informacije ili poveznice).

Razvoj knjižnične aplikacije za mobilne uređaje za hrvatske knjižnice općenito predstavlja velik korak, a s obzirom na potrebna financijska sredstva i posebna znanja, zasigurno će ostati u domeni predstavljanja specijalnih knjižničnih zbirki i prigoda koje mogu razvijati samo velike knjižnice. Isto vrijedi i za aplikaciju knjižničnog kataloga za mobilne uređaje.

Razmatrane knjižnice koriste samo tradicionalni način digitalne komunikacije, tj. kontakt-obrasce ili elektroničku poštu. S obzirom na raspoloživo osoblje i opseg posla s korisnicima, teško je predvidjeti širu primjenu komunikacije u realnom vremenu putem trenutnih poruka ili pričaonice, no ipak ne treba zanemariti komunikacijske mogućnosti koje pružaju društvene mreže i mediji, a na kojima su knjižnice zastupljene već dulji niz godina.

Društvene mreže i mediji postali su široko zastupljeni kod gotovo svih dobnih skupina, a korisnici mobilnih uređaja velik dio svog vremena provode na njima. ${ }^{78}$ Broj profila hrvatskih knjižnica na društvenoj mreži Facebook općenito je rastao u posljednjih deset godina ${ }^{79}$, pa je začudno da ga nema barem pola razmatranih knjižnica, pogotovo visokoškolskih, koje bi, ako već nemaju responzivne mrežne stranice, putem ove platforme mobilnim korisnicima mogle približiti svoje izvore i usluge.

78 Digital in 2018. Nav. dj., str. 63.

79 Pažur, I. Knjižnica. Nav. dj. 
Osim sporadične uporabe QR-koda, nove tehnologije i usluge (NFC, Beacon, AR) prema raspoloživim informacijama na knjižničnim mrežnim stranicama još nisu zaživjele te samo jedna knjižnica „eksperimentira“ s njihovim uvođenjem. S obzirom na trenutne nepovoljne uvjete, prvenstveno financijske, za očekivati je i da se neće primjenjivati u skorijoj budućnosti te da će se možda pojaviti kada postanu raširene u knjižnicama razvijenijih zemlja.

Iz rezultata dobivenih analizom sadržaja knjižničnih mrežnih mjesta vidljivo je da knjižnični izvori i usluge za mobilne uređaje nisu dovoljno prisutni u razmatranim hrvatskim visokoškolskim i srodnim knjižnicama koje podupiru znanstveni rad i visoko obrazovanje i u tom se smislu nisu prilagodile korisnicima. Međutim, iako se za sada ne radi o strateškom planiranju takva pristupa, knjižnice će, naročito visokoškolske, ako žele privući i zadržati tehnološki orijentirane generacije korisnika, morati uvažiti njihove nove i drukčije informacijske i komunikacijske potrebe koje je potrebno istražiti.

\section{LITERATURA}

Accart, J-P. Through the looking glass: envisioning new library technologies Augmented reality in the (real) library world - part one. // Library High Tech News 31, 1(2014). [citirano: 2019-10-15]. Dostupno na: https://doi.org/10.1108/LHTN-12-2013-0072.

Aharony, N. Librarians' attitudes towards mobile services. // Aslib Proceedings 65, 4(2013), 358-75. [citirano: 2019-10-15]. Dostupno na: https://doi.org/10.1108/AP07-2012-0059.

Aldrich, A. Universities and libraries move to the mobile web. // Educause Review, 2010. [citirano: 2018-4-11]. Dostupno na: https://er.educause.edu/articles/2010/6/ universities-and-libraries-move-to-the-mobile-web.

Ansari, M. S. Using WhatsApp for service providing in libraries and information centres. // Knowledge Librarian 3, 2(2016), 57-63. [citirano: 2018-4-11]. Dostupno na: http://www.klibjlis.com/3.1.8.pdf.

Ashford, R.; L. Zeigen. Mobile technology in libraries survey - academic libraries, 2012. [citirano: 2019-9-10]. Dostupno na: http://educationdocbox.com/Distance_Learning/74704001-Mobile-technology-in-libraries-survey-conducted-january-2012-by-robin-ashford-george-fox-university-and-laura-zeigen-ohsu-academic-libraries.html.

Ballard, T. L.; A. Blaine. A library in the palm of your hand. // New Library World 114, 5/6(2013), 251-58. [citirano: 2019-9-10]. Dostupno na: https://doi. org/10.1108/03074801311326876. 
Barnhart, F. D.; J. E. Pierce. Becoming mobile: reference in the ubiquitous library. // Journal of Library Administration 52, 6/7(2012), 559-570. [citirano: 2019-9-10]. Dostupno na: https://doi.org/10.1080/01930826.2011.556942.

Becker, D. A.; I. Bonadie-Joseph; J. Cain. Developing and completing a library mobile technology survey to create a user-centered mobile presence. // Library Hi Tech 31, 4(2013), 688-99. [citirano: 2019-9-10]. Dostupno na: https://doi.org/10.1108/LHT03-2013-0032.

Bess, M.; S. K. Wu; B. Price. 49er alerts: utilizing mobile marketing technology for library outreach. // Public Services Quarterly 11, 4(2015), 291-99. [citirano: 20199-10]. Dostupno na: https://doi.org/10.1080/15228959.2015.1088816.

Bomhold, C. Mobile services at academic libraries: meeting the users' needs? // Library Hi Tech 32, 2(2014), 336-45. [citirano: 2019-9-10]. Dostupno na: https://doi. org/10.1108/LHT-10-2013-0138.

Bridges, L.; H. G. Rempel; K. Griggs. Making the case for a fully mobile library web site: from floor maps to the catalog. // Reference Services Review 38, 2(2010), 309-20. [citirano: 2019-9-10]. Dostupno na: https://doi.org/10.1108/00907321011045061.

Caperon, L. Developing adaptable, efficient mobile library services: librarians as enablers. // Ariadne: web magazine for information professionals, 2015 [citirano: 20189-23]. Dostupno na: http://www.ariadne.ac.uk/issue73/caperon.

Carlucci Thomas, L. Gone mobile? (mobile libraries survey 2010). // Library Journal 135, 18(2010), 30-34. [citirano: 2019-10-17]. Dostupno na: https://eric.ed. gov/?id=EJ930803.

Consumer barometer from Google. [citirano: 2018-11-11]. Dostupno na: https://www. consumerbarometer.com/en/.

Cowell, A. E.; M. Jia. Doing research on mobile devices : an undergraduate case study. // College and Undergraduate Libraries 23, 4(2016), 414-26. [citirano: 2019-10-17]. Dostupno na: https://doi.org/10.1080/10691316.2015.1025938.

Dahlstrom, E.; C. Brooks; S. Grajek; J. Reeves. ECAR study of undergraduate students and information technology, 2015. [citirano: 2019-7-10]. Dostupno na: https://library. educause.edu/resources/2015/8/ /media/24ddc1aa35a5490389baf28b6ddb3693. ashx.

Digital in 2018: global overview. 2018. [citirano: 2018-12-16]. Dostupno na: https://www.slideshare.net/wearesocial/digital-in-2018-global-overview86860338?qid=7833f8c4-07ae-4975-9d18-61aef3fdb3e6\&v=\&b=\&from_sear$\mathrm{ch}=1$.

Digital in 2018 in Southern Europe part 2 - East. 2018. [citirano: 2019-9-12]. Dostupno na: https:/www.slideshare.net/wearesocial/digital-in-2018-in-southern-europepart-2-east-86864768. 
Eng, S. Connection, not collection: using IBeacons to engage library users. // 35, 10(2015), 12. Dostupno na: http://www.infotoday.com/cilmag/dec15/Eng--UsingiBeacons-to-Engage-Library-Users.shtml.

Global social networks ranked by number of users 2019. // Statista. [citirano: 20193-11]. Dostupno na: https://www.statista.com/statistics/272014/global-socialnetworks-ranked-by-number-of-users/.

Grey, A.; R. Isaac-Menard. Database mobile accessibility assessment at Adelphi University Libraries. // Journal of Web Librarianship 9, 2/3(2015), 85-98. [citirano: 2019-9-12]. Dostupno na: https://doi.org/10.1080/19322909.2015.1050567.

Hahn, J. Mobile augmented reality applications for library services. // New Library World 113, 9/10(2012), 429-38. [citirano: 2019-9-12]. Dostupno na: https://doi. org/10.1108/03074801211273902.

Hebrang Grgić, I.; D. Mučnjak. Social networking phenomenon and its use in libraries. // Croatian Journal of Education 17, 1(2015), 217-41. [citirano: 2019-3-11]. Dostupno na: https://hrcak.srce.hr/137849.

Jacobs, M. L. Libraries and the mobile revolution: remediation=relevance. // Reference Services Review 37, 3(2009), 286-90. [citirano: 2019-3-11]. Dostupno na: https:// doi.org/10.1108/00907320910982776.

Kim, B. The present and future of the library mobile experience. // Library Technology Reports 49, 6(2013), 15-28. [citirano: 2019-3-11]. Dostupno na: https://journals.ala. org/index.php/ltr/article/view/4506.

Kumar, A. Students opinion about the success of mobile technology in libraries: a case study of Jawaharlal Nehru University (JNU), New Delhi. // New Library World 115, 9/10(2014), 471-81. [citirano: 2019-10-17]. Dostupno na: https://doi.org/10.1108/ NLW-10-2013-0075.

Little, G. Keeping moving: smartphone and mobile technologies in the academic library. // Journal of Academic Librarianship, 37, 3(2011), 267-269. [citirano: 201910-17]. Dostupno na: https://doi.org/10.1016/j.acalib.2011.03.004.

Liu, Q. Y.; S. Briggs. A library in the palm of your hand: mobile services in top 100 university libraries. // Information Technology \& Libraries 34, 2(2015), 133-48. [citirano: 2019-10-17]. Dostupno na: https://ejournals.bc.edu/index.php/ital/article/ view/5650.

Lyerly, T. Mobile-fiendly vs mobile-optimization vs responsive design for websites. // Torspark, c 2016. [citirano: 2018-8-17]. Dostupno na: http://torspark.com/mobile-friendly-vs-mobile-optimized-vs-responsive-design/.

Market share of mobile operating systems 2010-2018 Croatia. // Statista. [citirano: 2019-3-11]. Dostupno na: https://www.statista.com/statistics/669610/market-share-mobile-operating-systems-croatia/. 
Massis, B. Using virtual and augmented reality in the library. // New Library World 116, 11/12(2015), 796-99. [citirano: 2019-10-17]. Dostupno na: https://doi.org/10.1108/ NLW-08-2015-0054.

McAuliffe, J. Mobile compatible vs. mobile optimized - what's the difference? // Leonardo (blog), 2012. [citirano: 2018-8-11]. Dostupno na: http://blog.leonardo.com/ mobile-compatible-vs-mobile-optimized-whats-the-difference/.

McCarthy, G.; S. Wilson. ISBN and QR barcode scanning mobile app for libraries. // The Code4Lib Journal, 13 (2011). [citirano: 2018-11-25]. Dostupno i na: http://journal.code4lib.org/articles/5014.

McHugh, S.; K. Yarmey. Near field communication: recent developments and library implications. // Synthesis Lectures on Emerging Trends in Librarianship 1, 1(2014), 1-93. [citirano: 2019-10-17]. Dostupno na: https://doi.org/10.2200/S00570ED1V01Y201403ETL002.

Meier, A. Comparative analysis: mobile device user research, 2010. [citirano: 20199-10]. Dostupno na: https://confluence.ucop.edu/display/CMDUR/Comparative+Analysis.

Mishra, A. S.; S. Kumar Umre; P. Kumar Gupta. Qr code in library practice some examples. // International Journal of Engineering Sciences \& Research Technology 6, 2(2017), 319-26. [citirano: 2019-10-17]. Dostupno na: http:/www.ijesrt.com/ issues\%20pdf\%20file/Archive-2017/February-217/47.pdf.

M-Libraries - library success: a best practices wiki. [citirano: 2019-9-10]. Dostupno na: https://infopeople.org/sites/default/files/webinar/2011/10-12-2011/M-Libraries wiki.pdf.

Mobile and tablet internet usage exceeds desktop for first time worldwide. // StatCounter global stats. [citirano: 2019-9-10]. Dostupno na:. http://gs.statcounter.com/press/ mobile-and-tablet-internet-usage-exceeds-desktop-for-first-time-worldwide.

Mobile social media. // Statista. [citirano: 2018-11-25]. Dostupno na: https://www.statista.com/topics/2478/mobile-social-networks/.

Murray, L. Libraries 'like to move it, move it.' // Reference Services Review 38, 2(2010), 233-49. [citirano: 2019-10-17]. Dostupno na:https://doi. org/10.1108/00907321011045007.

Novak, S. IBeacon - od buzzworda do realnog iskustva. // Plan B. [citirano: 2018-1024]. Dostupno na: http://planb.hr/ibeacon-od-buzzworda-do-realnog-iskustva/.

Nowlan, G. Going mobile: creating a mobile presence for your library. // New Library World 114, $3 / 4$ (2013), 142-50. [citirano: 2019-10-17]. Dostupno na: https://doi. org/10.1108/03074801311304050.

Pakdaman Naeini, M.; H. Sharif Moghaddam; S. Ziaei; A. Ghaebi. Mobile services in the libraries of the world's top universities. // Library Hi Tech. [citirano: 2019-1017]. Dostupno na: https://doi.org/10.1108/LHT-07-2017-0140. 
Pažur, I. Attitude of the Rudjer Boškovic Institute's scientists to the small screen mobile devices library services: a user survey. // Library Hi Tech 32, 4(2014), 628-44. [citirano: 2019-10-17]. Dostupno na: https://doi.org/10.1108/LHT-03-2014-0025.

Pažur, I. Hrvatske knjižnice na društvenoj mreži Facebook. // 13. seminar Arhivi, knjižnice, muzeji: mogućnosti suradnje u okruženju globalne informacijske infrastrukture. Zagreb: Hrvatsko knjižničarsko društvo, 2010. Str. 260-77. [citirano: 2019-810]. Dostupno i na: http://fulir.irb.hr/id/eprint/480.

Projekt NSK namijenjen razvoju pametnih knjižnica nagrađen u sklopu donacijskog natječaja Hrvatskog Telekoma „Generacija Next“, 2018. [citirano: 2019-10-15]. Dostupno na: http://www.nsk.hr/projekt-nsk-namijenjen-razvoju-pametnih-knjiznica-nagraden-u-sklopu-donacijskog-natjecaja-hrvatskog-telekoma-generacija-next/.

Pun, R. WeChat in the library: promoting a new virtual reference service using a mobile app. // Library Hi Tech News 32, 6 (2015), 9-11. [citirano: 2019-10-15]. Dostupno na: https://doi.org/10.1108/LHTN-03-2015-0017.

Purcell, K.; R. Entner; N. Henderson. The rise of apps culture. // Pew Research Center, 2010. [citirano: 2019-5-7]. Dostupno na: http://www.pewinternet.org/2010/09/14/ the-rise-of-apps-culture/.

Rawlins, B. Mobile devices: a practical guide for librarians. Lanham: Rowman \& Littlefield Publishers, 2015.

Rempel, H. G.; L. Bridges. That was then, this is now: replacing the mobile-optimized site with responsive design. // Information Technology and Libraries 32, 4(2013), 8-24. [citirano: 2019-10-15]. Dostupno na: https://doi.org/10.6017/ital.v32i4.4636 .

Karim, N. S. A.; S. H. Darus; R. Hussin. Mobile phone applications in academic library services: a students' feedback survey. // Campus-Wide Information Systems 23, 1(2006), 35-51. [citirano: 2019-10-15]. Dostupno na: https://doi. org/10.1108/10650740610639723.

Shatte, A.; J. Holdsworth; I. Lee. Mobile augmented reality based context-aware library management system. // Expert Systems with Applications 41, 5(2014), 2174-85. [citirano: 2019-10-15]. Dostupno na: https://doi.org/10.1016/j.eswa.2013.09.016.

Smart library: detaljan opis projekta. [citirano: 2019-10-15]. Dostupno na: https://www. generacijanext.hr/media/uploads/submissions/1 fd74a17d00247bbb6eedc7d13d3cfe9/smart_library_detaljan_opis_projekta_2018.pdf.

Sterling, G. It's official: Google says more searches now on mobile than on desktop. // Search Engine Land, 2015. [citirano: 2018-9-12]. Dostupno na: http://searchengineland.com/its-official-google-says-more-searches-now-on-mobile-than-on-desktop-220369.

Stropnik, A. Knjižnica za nove generacije: virtualni sadržaji i usluge za mlade. Zagreb: Hrvatsko knjižničarsko društvo, 2013. 
Tomić, D. Raste broj korisnika pametnih mobilnih telefona. // ICT Business, 2015. [citirano: 2018-8-19]. Dostupno na: http://www.ictbusiness.info/internet/ht-raste-broj-korisnika-pametnih-mobilnih-telefona.

Yusof, M. K.; A. Abel; M. Y. Saman; M. N. Abdul Rahman. Adoption of near field communication in S-Library application for information science. // New Library World 116, 11/12(2015), 728-47. [citirano: 2019-10-15]. Dostupno na: https://doi. org/10.1108/NLW-02-2015-0014.

Zak, E. Do you believe in magic? Exploring the conceptualization of augmented reality and its implications for the user in the field of library and information science. // Information Technology and Libraries 33, 4(2014), 23-50. [citirano: 2019-10-15]. Dostupno na:https://doi.org/10.6017/ital.v33i4.5638.

Zhao, Y.; S. Deng; R. Zhou. Understanding mobile library apps continuance usage in China: a theoretical framework and empirical study. // Libri 65, 3(2015), 161-73. [citirano: 2019-10-15]. Dostupno na https://doi.org/10.1515/libri-2014-0148. 